\title{
Labour not land constrains agricultural production and food self-sufficiency in maize-based smallholder farming systems in Mozambique
}

\author{
Wilson J. Leonardo ${ }^{1,2}$ • Gerrie W. J. van de Ven ${ }^{1}$ Henk Udo ${ }^{3}$. \\ Argyris Kanellopoulos $^{1,4} \cdot$ Almeida Sitoe $^{2} \cdot$ Ken E. Giller $^{1}$
}

Received: 4 April 2014 / Accepted: 8 June 2015 / Published online: 11 July 2015

(C) The Author(s) 2015. This article is published with open access at Springerlink.com

\begin{abstract}
Despite abundant land and favourable climatic conditions, Mozambique remains food insecure. We investigated the diversity, constraints and opportunities to increase smallholder productivity and achieve food self-sufficiency in maize-based farming systems in two Posts in central Mozambique. We identified four farm types in each village based on cultivated area and labour. Farm type 1 cultivated relatively large areas, owned cattle and hired in labour. Farm type 2 cultivated moderate areas and both hired in and hired out labour. Farms of type $3 \mathrm{a}$ and $3 \mathrm{~b}$ cultivated the smallest areas. Farm type 3a shared labour while Farm type 3 b only hired out labour. For each farm type, we calculated land and labour productivities of maize, sunflower and sesame and assessed maize self-sufficiency. Access to labour during weeding was the main constraint. The hiring out of labour by small farms caused severe reductions in both land and labour productivity. Yield reductions on these farms were due to delayed weeding in own fields. In one Post, Farm type $3 b$ was not maize self-
\end{abstract}

Electronic supplementary material The online version of this article (doi:10.1007/s12571-015-0480-7) contains supplementary material, which is available to authorized users.

Wilson J. Leonardo

wilson.leonardo@wur.nl

1 Plant Production Systems group, Wageningen University, P.O. Box 430, 6700 AK Wageningen, The Netherlands

2 Faculty of Agronomy and Forestry Engineering, Eduardo Mondlane University, P.O. Box 257, Maputo, Mozambique

3 Animal Production Systems Group, Wageningen Institute of Animal Sciences, Wageningen University, PO Box 338, 6700 AH Wageningen, Netherlands

4 Operations Research and Logistics Group, Wageningen University, PO Box 8130, 6700 EW Wageningen, The Netherlands sufficient. Labour quality was probably impaired by excess alcohol consumption among the poorer farmers (both men and women). Our results showed that production can be increased based on current agricultural practices. Farmers did not cultivate all of their land, suggesting that lack of labour constrained intensification by smallholder farmers.

Keywords Farm types - Labour use $\cdot$ Productivity $\cdot$ Alcohol consumption · Weeding

\section{Introduction}

Mozambique has abundant land and favourable agro-climatic conditions for agriculture (Batidzirai et al. 2006; MINAG 2008a). Yet it remains one of the poorest countries in world, ranking 184 out of 187 in the 2011 UN Human Development Index (UNDP 2011). To tackle this poverty, the Poverty Reduction Action Plan (PARP) identified increasing agricultural production by the smallholder farming sector as one of its main objectives (Moçambique 2011). Agriculture is the main source of food and income for nearly $70 \%$ of the Mozambican population who live in rural areas. Smallholdings account for $96 \%$ of the 5.6 million hectares of the total cultivated area and their farmers are responsible for $95 \%$ and $76 \%$ of the area allocated to food and cash crops, respectively (MINAG 2008b). The smallholder farming systems are capital extensive and use few inputs (World Bank 2006). Only $4 \%$ of the smallholder farmers apply fertilizers, $2 \%$ use animal traction (the other $98 \%$ relying on hand-hoeing) and $5 \%$ use irrigation. Thus the key resources available to farmers for agriculture are their land and labour.

Maize (Zea mays L.) is the staple food crop and occupies about $44 \%$ of the area allocated to basic food crops (INE 2011a). Consequently, it has been used to assess the food 
self-sufficiency of smallholders (SETSAN 2010; Schut et al. 2011; Milgroom and Giller 2013) and is the main component of food aid interventions (Tschirley et al. 2006).

The Strategic Plan for Development of the Agricultural Sector (PEDSA) emphasises the need for increasing smallholder productivity in order to achieve food security and increase farmers' income (MINAG 2011). PEDSA prioritises regions with a relatively high agricultural potential. Understanding the diversity of farmers and their access to and allocation of productive resources is essential in order to target farmers with improved technologies (Giller et al. 2011; Senthilkumar et al. 2009; Shepherd and Soule 1998).

Our objectives were to understand the diversity, constraints and opportunities in the maize-based smallholder farming systems of central Mozambique in order to identify options for increasing smallholder productivity and achieving food selfsufficiency. Given that smallholder farmers in Mozambique use few external inputs we focused on land and labour as the key resources for agriculture. The study was conducted on the Manica plateau in Manica province,

a target area for increasing smallholder food production (MINAG 2011).

\section{Materials and methods}

\section{Study site}

Manica province is situated in an agroecological zone with a relatively good potential for agriculture. We selected two Administrative Posts (Zembe and Dombe) based on expected competition for resources between food and cash crops and different distances to urban markets. Zembe Post is located at $19.295^{\circ} \mathrm{S}$ and $33.354^{\circ} \mathrm{E}$ whereas Dombe Post lies at $19.971^{\circ}$ $\mathrm{S}$ and $33.398^{\circ} \mathrm{E}$. Table 1 summarizes the main biophysical and socio-economic characteristics of the two Posts which are representative of villages in this part of Mozambique (see Table S1). Attributes of the households in the study area were similar to those from the national agricultural household survey (TIA) (MINAG 2008b; Table S1). There are two main seasons: the hot and wet season (November-March) and the cool and dry season (April-October). The region has a unimodal rainfall pattern that allows one main cropping season per year. Average annual rainfall over the last 15 years was $880 \mathrm{~mm}$ in Zembe and $930 \mathrm{~mm}$ in Dombe (USGS/FEWSNET 2011). The predominant soils in Zembe are Ferric Acrisols and Haplic Lixisols and in Dombe they are Eutric Fluvisols and Albic Arenosols (FAO-UNESCO 1988). In Dombe the terrain is relatively flat compared with the undulating terrain of Zembe. Chimoio city, the main urban market in the province is situated 25 and $145 \mathrm{~km}$ from Zembe and Dombe, respectively. The two Posts are $120 \mathrm{~km}$ apart.

\section{Rapid survey}

A rapid farm survey was carried out in Zembe and Dombe during the cropping season 2009-2010 as an entry point for characterizing farming systems. In Zembe we selected Catize and Charonga villages whereas in Dombe we selected Mabaia and Magalo villages. Based on discussions with agricultural officers, these villages are representative of smallholder farming systems in each administrative Post. Prior to systematic data collection, exploratory visits were made to each of the selected villages. From the visits we learnt that there was one main road crossing each village, which is characteristic of many villages in Mozambique. Starting from one of the entrances of the village we selected one out of every three households on both sides along the main road. In both Posts, footpaths branch from the main roads with a length of $100-1000 \mathrm{~m}$. We continued along the footpaths following the same pattern of selecting one out of every three households. Where the selected household was not available for an interview, the immediate next household was selected. A total of 52 of 3844 farmers in Zembe and 72 of 9837 farmers in Dombe (INE 2011b) were interviewed using a semi-structured questionnaire. Three focus group discussions per village were organized with farmers for cross-checking data. We also interviewed three key informants per site together with a local extension officer to cross-check data from the survey and the focus group discussions. The semi-structured questionnaires covered four topics a) demographics and crop production, b) livestock systems, c) off-farm activities, and d) markets. For demographics and crop production we looked at household and labour size, labour availability and distribution over agricultural activities, cropping systems, previous cropping history, cultivated crops, geometric patterns, field types, input used, production objectives (e.g. consumption or profit). For livestock systems we looked at type of animals owned by a household, feeding systems (e.g. communal land, crop residues), production objectives, crop - livestock interactions through manure, use of animal traction and crop residues. Off-farm activities investigated were: wage labour in town, self-employment and petty-trade, and income from temporal migration. With respect to the markets we covered the type of buyers, distances to markets and prices. During the group discussions composed of 6-8 people (50\% male and $50 \%$ female) we focused on understanding how land and labour limited production. We discussed the peak period of labour demand, interhousehold labour exchange and hiring out labour as well as the impacts on crop production, the use of animal traction in agriculture and the costs of labour. The interviews and focus group discussions were conducted in local languages (Chiute in Zembe and Ndau in Dombe) with the help of a local interpreter and each took 40 to $60 \mathrm{~min}$. 
Table 1 The main biophysical, socio-economic and production characteristics in Zembe and Dombe

\begin{tabular}{|c|c|c|c|}
\hline & Units & Zembe & Dombe \\
\hline \multicolumn{4}{|l|}{ Biophysical characteristics } \\
\hline Area of administrative Post & $\mathrm{km}^{2}$ & 1475 & 2041 \\
\hline Precipitation & $\mathrm{mm}$ & 880 & 930 \\
\hline Topography & & $\begin{array}{l}\text { Moderately undulating } \\
\text { (Slopes 0-8\%) }\end{array}$ & $\begin{array}{l}\text { Relatively flat } \\
\text { (Slopes 0-2 \%) }\end{array}$ \\
\hline Predominant soil types & & $\begin{array}{l}\text { Ferric Acrisols, Haplic } \\
\text { lixisols }\end{array}$ & Eutic fluvisols, Arenosols \\
\hline Organic matter & $\%$ & $0.5-6.0$ & $0.5-5.0$ \\
\hline \multicolumn{4}{|l|}{ Socio-economic indicators } \\
\hline $\begin{array}{l}\text { Average cultivated area per } \\
\text { farm }\end{array}$ & ha & 1.7 & 2.1 \\
\hline Population density & inhab. $\mathrm{km}^{-2}$ & 12.8 & 24.2 \\
\hline Distance to Chimoio city & $\mathrm{km}$ & 25 & 145 \\
\hline Biofuel investments & & Jatropha & Sugarcane \\
\hline \multicolumn{4}{|l|}{ Main production activities } \\
\hline Food crops & & Maize, sorghum, cowpeas & Maize, sorghum, cowpeas \\
\hline Cash crops & & Sunflower & Sesame, maize \\
\hline Livestock & & Village poultry, goats, cattle & $\begin{array}{l}\text { Village poultry, goats, } \\
\text { cattle }\end{array}$ \\
\hline
\end{tabular}

Sources: (INE 2011b; FAO 1988; SDAE-Gondola, 2012; SDAE-Sussundenga, 2011)

\section{Farm typology}

The information from the rapid survey was first explored by principal components analysis (PCA), using Canoco for Windows version 4.5 (Jongman et al. 1995). Twenty five variables were included (Table 2). The PCA was used with the objective of exploring relationships within the complex array of variables. PCA can help in the understanding of which variables can best be used to explain the largest part of the variability found in the data. PCA results were combined with participant observations on the main activities (cultivating crops), information on the tools used and use of external inputs. This resulted in the definition of four farm types. Next, the farm typology was validated in group discussions with farmers in both Posts and checked using independent variables collected during the rapid survey. Statistical differences between the Posts were tested using t-tests while differences among farm types were tested using one-way ANOVA. Two nonparametric tests were used: the KruskalWallis test was used to determine differences between farm types for variables which were not normally distributed, such as the number of household labourers, the number of cattle, and the number of goats and chickens. The Chi-Square test $\left(\chi^{2}\right)$ was used to determine farm type differences for the categorical variables such as gender of household head. To assess the differences between pairs of farm types, we used two multiple posthoc tests, Tukey HSD and the Mann-Whitney Test. The first was used for those variables that meet the assumption of homogeneity of variances and the latter for variables that did not meet this assumption. All statistical comparisons were made at $\alpha=$ 0.05 significance level using SPSS for Windows 10.0.

\section{Detailed survey}

For each village, three farms per farm type were selected for more detailed analysis of the farming system. These farms were chosen to represent the range of cultivated area and the common soil types in each village. The detailed data collection focused on crop yields, labour input and on data related to food self-sufficiency. The information on labour input per activity and the timelines per activity were combined to produce a crop labour calendar. Data from the detailed survey were crosschecked by discussing preliminary results with the farmers.

\section{Performance indicators}

\section{Land and labour productivities at field level}

Maize and sesame crop yields $\left(\mathrm{kg} \mathrm{ha}^{-1}\right)$ were based on onfarm yield measurements and are expressed at 12 and $18 \%$ moisture, respectively. Before the yield measurements were taken, we walked with each farmer to the centre of the field. Four samples for yield measurements were taken from plots of $7 \mathrm{~m} \times 7 \mathrm{~m}$, one plot located at the centre of a "Y frame" and the other three plots at half distance to the end of each of the arms (Tittonell 2008). Crop samples were taken from each field and dried in the sun for two days prior to weighing. For sunflower, yields were expressed as $\mathrm{kg} \mathrm{ha}^{-1}$. Total crop production and revenue (US\$) per hectare were calculated for maize, sunflower and sesame in sole crop and in relay-intercropping systems. An exchange rate of 1 Metical (MT: Mozambican currency) to 0.035 US\$ was used (www.oanda.com; August 9, 2013). 
Table 2 Household characteristics used as variables in the principal components analysis (PCA)

\begin{tabular}{|c|c|c|}
\hline Input variable & Unit & Abbreviation used in Fig. 5. \\
\hline Gender of head of household & dummy & gender \\
\hline Household members providing labour for agricultural activities & \# & hh labour \\
\hline Household size & \# & hh size \\
\hline Households that hire labour to assist with cropping activities & - & hire labour \\
\hline Households cultivating improved sesame variety & dummy & I_variety \\
\hline Total land area cultivated by the household & ha & area \\
\hline Land labour ratio (area over the hh labour) & ha person ${ }^{-1}$ & LLR \\
\hline Households that obtained the current cultivated land through heritage system & - & inherited land \\
\hline Households that obtained the current cultivated land from relatives & - & relatives_land \\
\hline Households that obtained the current cultivated land from traditional leader (regulo) & - & regulo_land \\
\hline Households acquiring capital goods on top of the land that sustain it and obtain the right to use the land. & - & bought land \\
\hline Household that only hire labour and do not hire out labour & dummy & only hire labour \\
\hline Number of chickens owned & \# & \# chickens \\
\hline Number of cattle owned & \# & \# cattle \\
\hline Total number of fields owned & \# & \# fields \\
\hline Number of goats owned & \# & \# goats \\
\hline Households with permanent jobs outside agriculture & dummy & full off-farm \\
\hline Households with temporal jobs outside agriculture & dummy & temporal off-farm \\
\hline Self-employment and petty trade & dummy & other enterprises \\
\hline Hiring out labour & dummy & sale labour \\
\hline Growing cash crops (maize not included). & dummy & cash crop \\
\hline Tools to prepare the land & - & tools \\
\hline Crop exclusively cultivated for market & - & Cash crop \\
\hline The first preferred market used by the households for sale of sunflower & - & sunflower MKT1 \\
\hline The second preferred market used by the households for sale of sunflower & - & sunflower MKT2 \\
\hline
\end{tabular}

Crop labour productivity $\left(\mathrm{kg} \mathrm{h}^{-1}\right)$ was defined as the crop production per hour of both own and hired labour. In both Posts, children between 10 and 12 years of age performed some of the farming activities. Based on focus group discussions with farmers, we estimated the child labour contribution as equivalent to $1 / 4$ of adult labour. Data on labour input per activity was provided for the total crop area. Given that the hours worked per day differed among farm types, man-days were converted into man-hours for the comparisons. Labour input per ha was calculated by dividing the time spent by the area of the crop.

During the surveys we observed a large proportion of household members in both Posts had consumed alcohol even early in the morning and during the busy periods when labour demands for planting and weeding were heavy. Also during the focus group discussions it was mentioned that farmers hiring out labour tended to consume excessive amounts of alcohol. Our calculations of labour input for farm operations did not indicate a great shortage of labour - which implies that the quality of the labour was poor, perhaps due to the influence of alcohol. Therefore, it was decided to collect information on alcohol consumption, which could be used to infer the quality of labour. Using the list of households from the rapid survey, we first collected data on breath alcohol content in 124 households (52 in Zembe and 72 in Dombe), including the 12 case study farmers. During making the measurements, many of the neighbouring farmers showed interest in participating; therefore we collected data from an additional 32 and 20 farmers from Zembe and Dombe, respectively. Measurements were taken each day during a period of two weeks for an equal number of farmers per farm type. The measurements were made between the growing season and next rains for the following two reasons. First the farmers (both wealthier and the poorer farmers who worked as labourers) were busy during the growing season. Secondly, measurements made around harvest time could be influenced by the extra money available from sale of produce and therefore not representative. Only the head of each household participated. The data were collected between 9.00 and $11.00 \mathrm{~h}$ using a Daisy Al 7000 alcohol digital breathalyzer (http://www. digitalbreathalysers.co.uk/al7000-breathalyser.html) and weekends were avoided. A threshold value of $0.6 \%$ was used to judge whether alcohol consumption was likely to affect labour quality. This threshold is the blood alcohol content limit above which it is illegal to drive in Mozambique. 


\section{Maize self-sufficiency at farm level}

Maize self-sufficiency is a clear objective of all farmers. The food self-sufficiency ratio for maize (FSS) was calculated as the annual on-farm maize production divided by the household's annual needs. A value of FSS greater than or equal to one indicates maize self-sufficiency. A value below one indicates a maize deficit. The household need was based on detailed interviews with women at the homestead. They estimated the average quantity of shelled maize consumed by all household members over a month. This quantity was multiplied by 12 to calculate the consumption per year assuming the same quantity consumed in each month. Using an annual time period allows us to have a general understanding of the likely maize consumption within a household. Seasonality was not accounted for, even though it might help to better understand the variability of maize consumption across months. We collected data around two months after harvesting which may be a better indication of the amount that farmers would like to consume compared with other periods. For instance, in the lean season the amount of maize available and therefore consumed may be less than desired as reducing the number of meals is a coping strategy. Annual maize consumption was cross-checked with available data from other regions in the country where maize is also a staple food (Lukanu et al. 2007; Tschirley et al. 2006) and was found to be within the same range. No data on post-harvest losses due to the main pest, the large maize borer (Sitophilus zeamais), was available in either Posts.

\section{Land and labour productivities at farm level}

The average crop yields from on-farm measurements were converted into monetary value $(\mathrm{Mt})$ by multiplying the total yield per farm with the farm gate price (revenues). Price data collected by the Agricultural Marketing System of Mozambique (SIMA) neither include sesame and sunflower nor cover Zembe and Dombe Posts. Thus, we interviewed farmers, farmers associations and itinerant buyers to obtain farm gate prices. Maize was sold in local units (gallon or 20 litre tin) and was converted into SI units. Sesame and sunflower were sold per $\mathrm{kg}$. Maize prices varied over the year. The amount of maize used for home consumption was valued at the price at harvest. To value the maize surplus we used three farm gate prices: the price at harvest (April to July), during the middle period (August to November) and during the lean period (December to March). The surplus sold for each of the three prices was estimated. The prices of sunflower and sesame were fixed. Land and labour productivities at farm scale were calculated as:

FarmRevenue $=\sum_{c=1}^{n} Y_{c} \times P_{c} \times A_{c} \quad(M t)$

FarmFINLabour $=$ FarmRevenue $/ \sum_{c=1}^{n} h_{c}\left(M t h^{-1}\right)$

where FarmRevenue is the total revenue in the farm, $Y_{c}$ is the average yield of crop $c$ in $\mathrm{kg}$ per ha, $p$ is the farm-gate price of the crop $c$ in Mt, $A$ is the area occupied by crop c on the farm, $n$ is number of crops, FarmFINLabour is the farm financial labour productivity and $h_{c}$ is the time (including hired labour) spent to produce crop $c$.

We calculated labour productivity as the total revenues minus the costs, including the hired labour, divided by the number of days worked by family members. We compared this with the minimum wage in the farming sector in Mozambique. The cost for hired labour was set at 2.1 US\$ per day, based on the detailed survey. The minimum daily wage in the farming sector was calculated from the monthly wage of 81.3 US\$, based on national minimum wage (Moçambique 2012), divided by 22 working days in a month, resulting in 3.7 US\$ per day. To compare with data in the Third National Poverty Assessments (Alfani et al. 2012) expressed in US\$ per worker per year, we divided the total annual farm revenue minus costs by the number of labourers. A third comparison made was with the Manica Province poverty line, which is expressed in US\$ per capita per day and amounts to 0.60 US\$. We divided the total annual farm revenues by the number of workers and 365 days.

\section{Results and discussion}

\section{The farming system}

The rapid and detailed surveys confirmed that rain-fed maize was the major crop, grown in more than $90 \%$ of the cropped fields in both Posts. An exception was the larger-scale farmers in Dombe where one quarter of the cultivated area was occupied by sesame. Sunflower, sesame and sorghum were grown as relay-intercrops with maize, on only part of the cultivated area. For sesame, an improved variety was cultivated as a sole main crop. Sunflower, sesame and sorghum were planted in holes between the maize rows as relay crops. The resulting pattern for maize-sunflower, maize-sesame and maize-sorghum was 1:1. Seeds of pumpkins and cowpeas were mixed with maize at planting on the remaining part of the cultivated area. In Dombe, maize was cultivated for food and cash by all farmers. In Zembe, only $17 \%$ of the farmers grew maize for food and cash. Some farmers in Zembe grew vegetables (mainly kale and onion) in fields alongside river banks, which they sold at Chimoio market. Only $25-30 \%$ of the farmers who have such 
fields cultivated them every season. The vegetable season starts after the second weeding of maize at the end of the rainy season.

In Dombe there is a huge demand for maize from buyers from southern and central Mozambique, in particular from the main maize milling company in central Manica (Empresa Nacional Desenvolvimento e Comercializaçao Agrícola DECA). Although Dombe is about $1000 \mathrm{~km}$ north of Maputo, it is the region closest to the capital where maize can be sourced. By contrast, farmers in Zembe rely on itinerant buyers from Chimoio or alternatively they transport their produce about $25 \mathrm{~km}$ by bicycle for sale in the town. The proximity of Zembe to Chimoio offers opportunities for non-agricultural related earnings. Barrett et al. (2001) and Lanjouw et al. (2001) found the proximity to urban areas to be a major factor influencing smallholder farmers to diversify into non-agricultural activities.

Figure 1 shows the timeline of the main agricultural activities and crop sequence for maize, sunflower, sesame, sorghum and vegetables in Zembe and Dombe from the rapid survey.

In both Posts, weeding was consistently said by the farmers to be the most important and most labour demanding activity. Farmers from both sites relied on hand-hoeing and none of them used herbicides. While the rapid survey showed that 35 and $38 \%$ of farmers used animal traction in Zembe and Dombe, respectively, the interactions between crops and livestock were limited to land preparation and transport of harvested products. The farmers reported that lack of animaldrawn weeding tools hampered the use of animal traction for weeding. Larger farms hired additional labour during the first weeding of maize. From interviews with individual farmers and key informant farmers in Zembe, we learnt that when animal traction was used to prepare the land for maize, there was no need for a second weeding, in contrast to land preparation by hand. While animal traction was also used in Dombe, the farmers still weeded their maize fields twice. In both Posts, relay-intercropping was said to be a strategy that allowed farmers to avoid using labour to cultivate new land.

Although the majority of farmers cultivated less than 2.5 ha in both Posts, farmers in Zembe cultivated relatively smaller areas $(<3.5$ ha, with an average of 1.2 ha) compared with Dombe where several farmers cultivated 5 to 8 ha, averaging 2.1 ha. According to the Mozambican land system, land is the property of the State. Two land tenure arrangements predominated in the two Posts: Inheritance and through traditional leader (regulo). The regulo has the right to allocate land to someone who asks for it. We learnt that if a piece of land is not used for more than five to six years, the regulo can allocate it to someone else. The cultivated area was not the same as farm size as all farmers leave roughly $25 \%$ of their land fallow. The rapid survey showed that 55 and $60 \%$ of the farmers left land fallow for 1-5 years in Zembe and 1-6 years in Dombe. Maintenance of soil fertility and avoiding soil erosion were achieved by the fallow system and retention of crop residues of maize and sorghum in the field. Soil chemical analysis (Table 3) suggested that the most limiting nutrient for crop production was nitrogen in both Posts, but that phosphorus was limiting only in one soil type in Zembe. Potassium concentrations were relatively high.

Free range chickens were the most abundant livestock in both Posts. Farmers indicated that chickens were kept primarily as a source of cash for daily expenditures such as milling grains, buying household necessities such as soap, and school fees. Goats were next in abundance followed by cattle. More households in Dombe (57\%) kept goats than in Zembe (39\%). Only $14 \%$ of households in Zembe and $11 \%$ in Dombe kept cattle. The cattle were grazed extensively. Cattle herding was done by one child in the household after they had participated in crop production. Cattle were sometimes herded together with those of neighbours. Therefore, overall we assumed that there was no substantial competition between labour used to care for cattle and that used for cropping practices. None of the farmers in either village applied animal manure to arable fields.

\section{Farm typology}

\section{Farm categorisation}

The PCAs highlighted the similarities between the farming systems in the two Posts (Fig. 2). The first two principal components together captured $56.3 \%$ of the variability of household characteristics in Zembe and 59.6\% in Dombe. Table 4 shows the loadings for the correlation matrix for 20 and 21 household characteristics in Zembe and Dombe, respectively. The loading values indicate that variables related to land and labour, the principal resources available to the farmers, could be used to categorize farms as key variables. Although the PCA highlighted the strong contribution of the numbers of goats and chickens to the first two principal components, these variables can fluctuate wildly and were not considered useful for characterization. Based on results of the PCA (Fig. 2), focus group discussions and participant observation, four cases of labour dynamics were identified: (1) households only hiring labour (9 in Zembe and 17 in Dombe); (2) households hiring in and hiring out labour (23 in Zembe and 22 in Dombe); (3) households that shared labour (8 in Zembe and 22 in Dombe); (4) households only hiring out labour (12 in Zembe and 11 in Dombe). When farms were grouped, based on these criteria for labour dynamics, the area of land cultivated was found to differ strongly among the groups (Fig. 3). Thus we used these two criteria, labour dynamics and cultivated area to group the farms into farm types. In Zembe, 8 out of 9 households that cultivated more than 1.8 ha were those that only hired in labour. In Dombe, the cut off between these groups was 2.5 ha. These two values (1.8 ha and 2.5 ha) were used as the lower limit to identify Farm type 1: only hiring in labour. The same approach was used to distinguish households only hiring out labour (mutrakita - Farm type 3), resulting in upper limits for the cultivated area of 0.9 ha in Zembe and 1.4 ha in Dombe. More 


\section{Zembe Post}

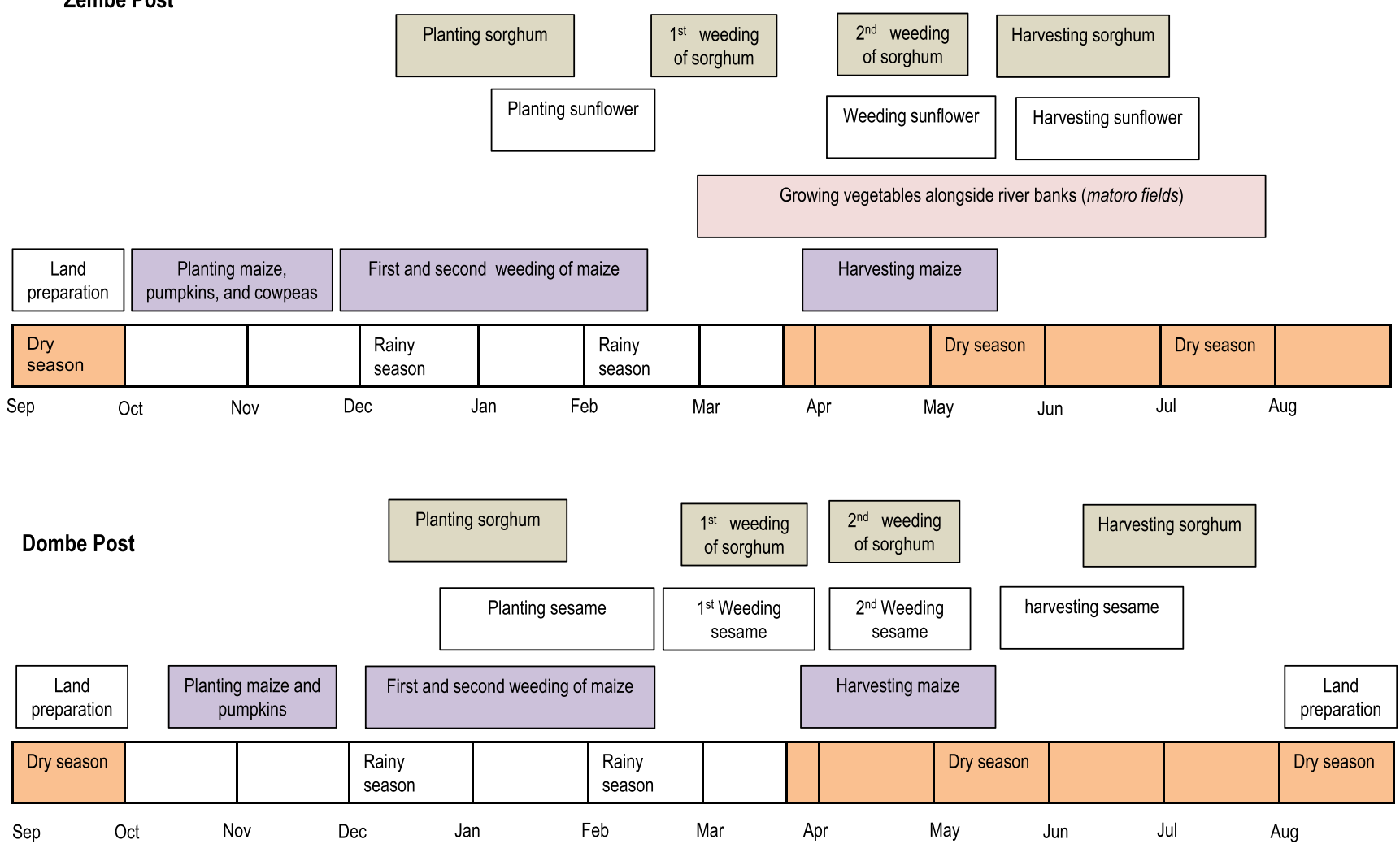

Fig. 1 Cropping seasons and timeline of the main agricultural activities for the main cultivated crops including vegetables cultivated on river banks in Zembe and Dombe

than half of the households fell into the 'hiring in and out' category of Farm type 2 in both Posts. Further analysis showed that those households with cultivated area equal or less than 0.9 ha in Zembe and 1.4 ha in Dombe, did not hire but shared labour (exchanging labour with neighbours) locally called gúmuè. To capture this diversity within the group, households that shared labour were named Farm type 3a. Six and fourteen households in Zembe and Dombe, respectively, fell into the "neither hiring in or out" category. These households were grouped into different farm types according to the size of their cultivated area. For instance, if a household in Dombe that neither hired in or hired out labour and had a cultivated area of 1.6 ha, we placed them in Farm type 2, and so on. The cultivated area was significantly different among Farm types 1 to 3 (Table 5). Farm types $3 \mathrm{a}$ and $3 \mathrm{~b}$ cultivated similar areas of land.

\section{Farm characterisation}

The Posts significantly differed in average cultivated area (2.1 vs. 1.2 ha), in mean number of people per household (7.4 vs. 5.5 persons) and, in mean land to labour ratio (LLR, 0.5 vs. 0.4 ha per person) with Dombe having the larger farms and households
Table 3 Soil properties for four different soil types as found in Dombe and Zembe administrative Posts

\begin{tabular}{|c|c|c|c|c|}
\hline & \multicolumn{2}{|l|}{ Zembe } & \multicolumn{2}{|l|}{ Dombe } \\
\hline & Soil type 1 & Soil type 2 & Soil type 1 & Soil type 2 \\
\hline N (\%) & 0.07 & 0.13 & 0.12 & 0.1 \\
\hline SOC (\%) & 1.4 & 1.4 & 1.6 & 1.4 \\
\hline $\mathrm{pH}\left(\mathrm{H}_{2} \mathrm{O}\right)$ & 5.8 & 5.9 & 5.6 & 5.7 \\
\hline Olsen P (mg kg $\left.{ }^{-1}\right)$ & 25.4 & 2.5 & 46.2 & 18.4 \\
\hline Exchangeable $\mathrm{K}\left(\mathrm{cmol}_{\mathrm{c}} \mathrm{kg}^{-1}\right)$ & 0.8 & 0.9 & 0.6 & 0.6 \\
\hline Clay $(\%)$ & 24 & 26 & 24 & 21 \\
\hline Silt (\%) & 12 & 12 & 33 & 15 \\
\hline Soil type & Sandy clay loam & Sandy clay loam & Loam & Sandy clay loam \\
\hline Soil local name & Tchica+Djetcha & Tchica & Djiho + Djetcha & Djiho \\
\hline
\end{tabular}



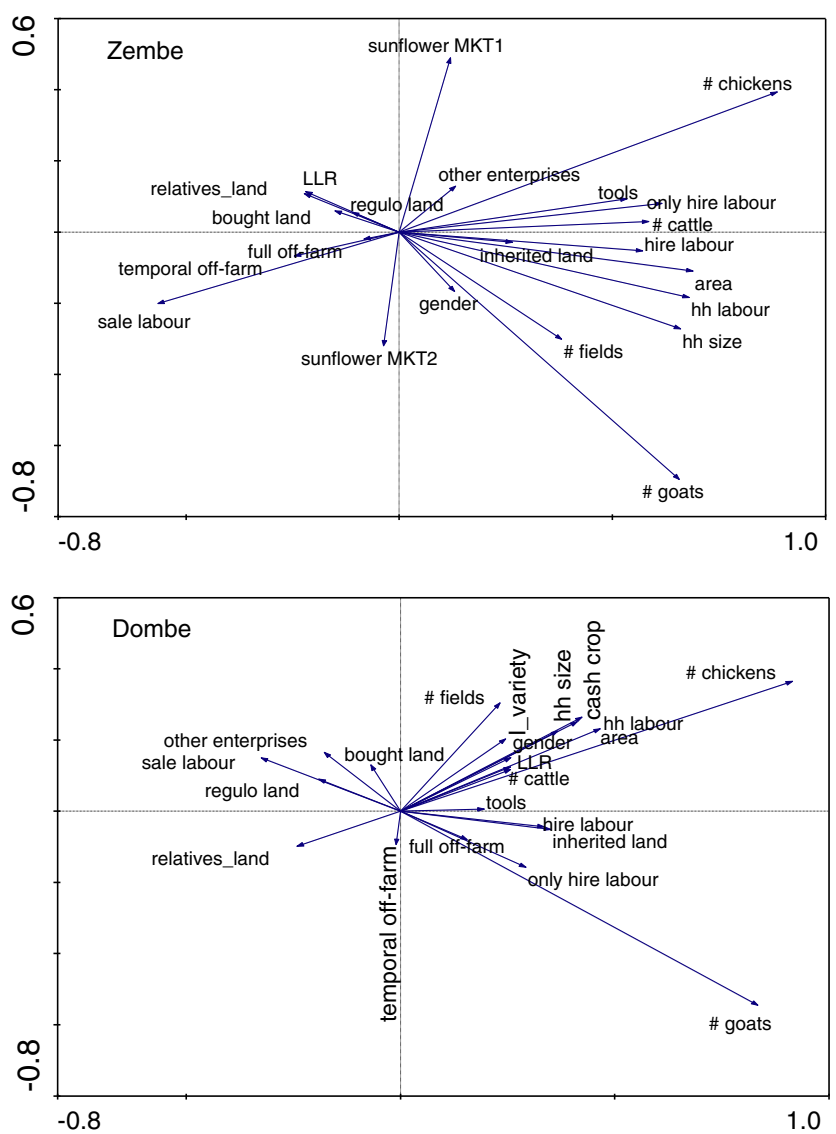

Fig. 2 Vectors showing the contribution of variables to the first two principal components in Zembe and Dombe from a principal component analysis. Abbreviations are given in Table 2

and more people below 12 years of age (Table 5). We did not observe any significant difference in number of female headed households between the Posts (16 in Zembe and 15 in Dombe). The farm types in both Posts were similar in terms of farm size pattern and labour dynamics, but the absolute values of the variables differed somewhat. The larger farms had significantly more household members $(P=0.002)$ in both Posts (Table 5). The number of labourers in the four types did not differ between the two Posts although these were significantly greater in Farm Type 1 . The land to labour ratio (LRR) was significantly higher in Farm type 1 ( 0.8 ha person $^{-1}$ in Dombe) and ( 0.6 ha person $^{-1}$ in Zembe) than in the other farm types. In both sites, Farm types $3 \mathrm{a}$ and $3 \mathrm{~b}$ tended to have the most female-headed households, whereas households of Farm type 1 were mainly male-headed households. In Zembe Farm type 1 was exclusively comprised of male-headed households. A study in Sussundenga district (Sousa 1999), where Zembe is located, showed that femaleheaded households were the poorest with severe constraints to the improvement of their livelihoods due to inequality in asset ownership. In our case-studies, the female-headed households were mostly divorced or widowed. They often suffered from social exclusion as they were perceived to be connected with witchcraft or prostitution.
Table 4 Loading values for the correlation matrix for 22 and 21 household characteristics in Zembe (a) and Dombe (b)

\begin{tabular}{|c|c|c|c|c|}
\hline \multirow[t]{2}{*}{ Variables } & \multicolumn{4}{|c|}{ Principal Components } \\
\hline & 1 & 2 & 3 & 4 \\
\hline \multicolumn{5}{|l|}{ A) Zembe } \\
\hline \# chickens & 0.879 & 0.410 & -0.231 & 0.027 \\
\hline hh labour & 0.714 & -0.198 & 0.487 & -0.139 \\
\hline area & 0.682 & -0.104 & 0.375 & -0.031 \\
\hline hh size & 0.676 & -0.287 & 0.502 & -0.165 \\
\hline \# goats & 0.657 & -0.680 & -0.298 & 0.025 \\
\hline only hire labour & 0.619 & 0.078 & 0.305 & -0.425 \\
\hline \# cattle & 0.596 & 0.016 & 0.587 & 0.412 \\
\hline hire labour & 0.568 & -0.047 & 0.069 & -0.382 \\
\hline sale labour & -0.567 & -0.201 & -0.188 & 0.474 \\
\hline tools & 0.543 & 0.079 & 0.610 & 0.405 \\
\hline \# fields & 0.393 & -0.313 & 0.379 & 0.124 \\
\hline inherited land & 0.262 & -0.023 & 0.003 & 0.545 \\
\hline temporal off-farm & -0.252 & -0.062 & -0.137 & 0.189 \\
\hline LLR & -0.246 & 0.131 & -0.339 & 0.130 \\
\hline relatives_land & -0.216 & 0.094 & 0.302 & -0.155 \\
\hline bought land & -0.154 & 0.066 & -0.305 & -0.232 \\
\hline gender & 0.132 & -0.169 & 0.111 & -0.359 \\
\hline full off-farm & 0.128 & 0.133 & -0.056 & 0.271 \\
\hline sunflower MKT 1 & 0.118 & 0.485 & 0.252 & -0.226 \\
\hline regulo land & -0.113 & 0.055 & 0.025 & -0.271 \\
\hline other enterprises & -0.081 & -0.021 & -0.094 & -0.493 \\
\hline sunflower MKT 2 & -0.040 & -0.312 & -0.194 & -0.211 \\
\hline \multicolumn{5}{|l|}{ B) Dombe } \\
\hline \# chickens & -0.700 & 0.342 & 0.090 & 0.056 \\
\hline area & -0.649 & -0.097 & -0.043 & 0.568 \\
\hline hire labour & -0.585 & -0.334 & -0.016 & -0.213 \\
\hline cash crop & -0.572 & 0.042 & -0.227 & -0.496 \\
\hline hh labour & -0.556 & 0.491 & -0.270 & 0.298 \\
\hline sale labour & 0.541 & 0.406 & -0.300 & 0.081 \\
\hline only hire labour & -0.505 & -0.617 & 0.087 & -0.215 \\
\hline hh size & -0.496 & 0.393 & -0.249 & 0.329 \\
\hline LLR & -0.469 & -0.346 & 0.107 & 0.430 \\
\hline relatives_land & 0.416 & -0.227 & 0.306 & 0.186 \\
\hline \# goats & -0.407 & 0.107 & 0.391 & -0.129 \\
\hline gender & -0.386 & 0.144 & -0.139 & 0.166 \\
\hline \# fields & -0.370 & 0.310 & -0.176 & -0.151 \\
\hline I_variety & -0.355 & 0.080 & -0.258 & -0.674 \\
\hline \# cattle & -0.330 & -0.169 & 0.262 & 0.256 \\
\hline full off-farm & -0.322 & -0.195 & 0.416 & -0.157 \\
\hline inherited land & -0.170 & 0.662 & 0.479 & -0.206 \\
\hline other enterprises & 0.137 & 0.043 & -0.667 & 0.052 \\
\hline temporal off-farm & 0.131 & 0.263 & 0.283 & 0.237 \\
\hline regulo land & -0.116 & -0.531 & -0.621 & 0.140 \\
\hline bought land & 0.062 & 0.128 & -0.254 & -0.119 \\
\hline
\end{tabular}

The variables are ranked in importance to the first principal component 

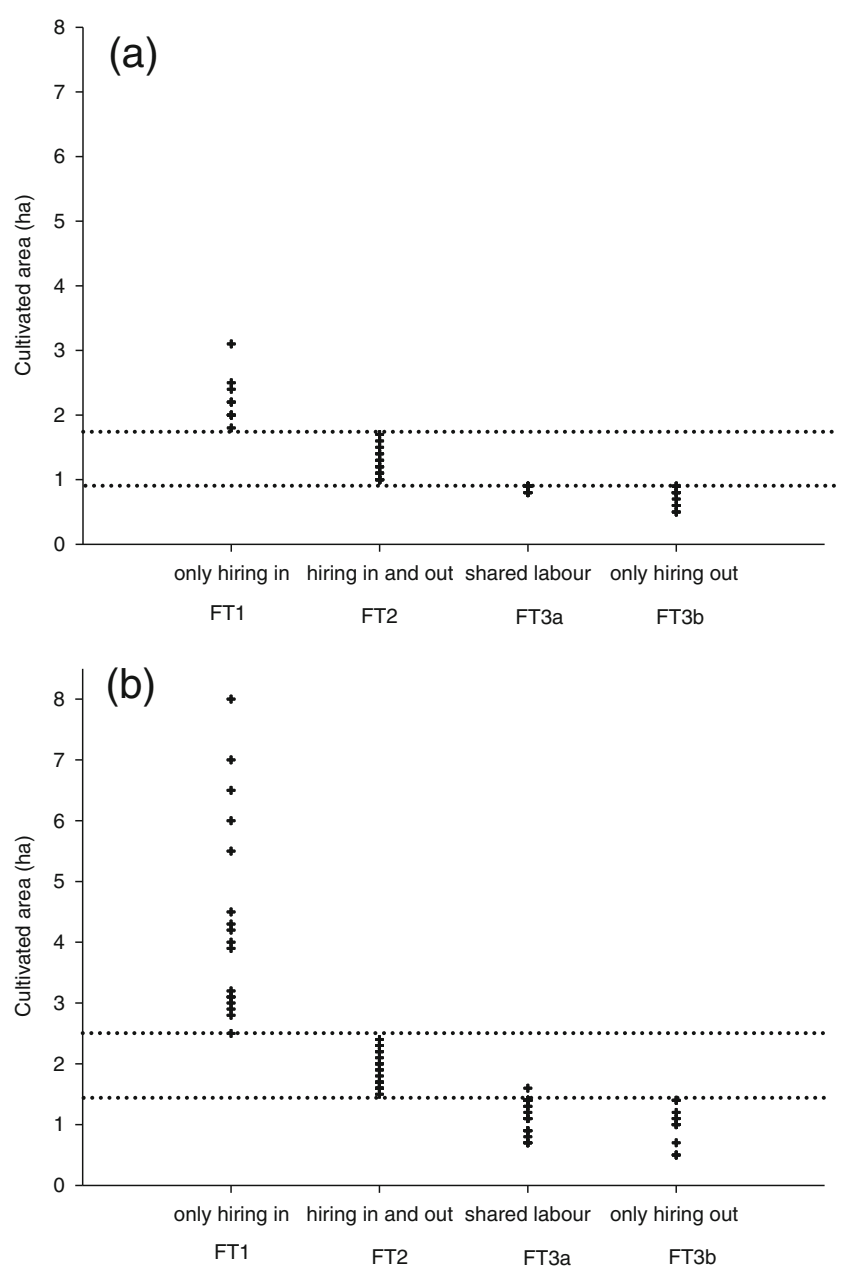

Fig. 3 Cultivated area of all farms related to four types of labour dynamics in (a) Zembe $(n=52)$ and (b) Dombe $(n=72)$ and the classification in farm types

The number of chickens owned by Farm type $3 \mathrm{~b}$ was significantly smaller in both Posts and in 3a in Dombe (Table 5). The number of goats differed significantly between the farm types only in Dombe $(P=0.039)$. In Dombe only Farm type 1 owned cattle, whereas in Zembe Farm types 1 and $3 \mathrm{a}$ and $3 \mathrm{~b}$ had cattle. Thus Farm type 1 contained the relatively wealthier farmers in the two Posts. They had more land, better access to labour, more livestock and were more market oriented. The use of animal traction on Farm type 1 was limited to land preparation, as none of the farmers owned cultivators, which led to labour constraints during the weeding phase, which they overcame by hiring labour.

\section{Labour demand and availability during the growing season}

There was a strong seasonality in labour required for cropping activities (Figs. 1 and 4). Peak demand for labour occurred in December and January-February during the 1st and 2nd weeding and in April during the harvest of maize and weeding of sunflower and sesame. The maximum availability of labour in the farm, indicated by the dashed line (Fig. 4), comprises both adult and child labour with long days due to time pressure. Land preparation was exclusively done by adults and was spread over a long period before the rainy season started. Children worked in the fields only during sowing, weeding and harvesting. Farm type 1 was constrained by farm labour availability during weeding of maize, when they hired in labour. Labour was always hired from people living in the vicinity from Farm types 2 and/or 3b. On average, Farm type 1 hired in $120 \mathrm{~h}$ in Zembe and $170 \mathrm{~h}$ in Dombe (Table 6). There were periods of slack labour during the cropping season, and especially during the dry season from May to August (Fig. 4). Some of this labour was used to grow other crops, and some for non-agricultural related activities (Fig. 5). Less than $25 \%$ of all households had no additional activities. In Dombe, $80 \%$ of the farmers engaged in only one additional activity. In Zembe, with the exception of Farm type 1, all the other farm households engaged in more than one non-agricultural related activity, such as charcoal production or firewood collection from uncultivated land.

For cattle keeping households, one family household member (most often a child) spent approximately $7 \mathrm{~h}$ per day herding cattle. Goats were tethered in fallow land close to the homestead during the cropping season and demanded hardly any labour (c. $10 \mathrm{~min}$ for tethering each day). During the offseason period the goats grazed freely on crop residues, and no labour was required as the animals returned to the homestead at end of the day. Farmers did not keep goats in kraals.

\section{Land and labour productivities at field level}

In general the maize grain yields per ha were greater in Dombe than in Zembe (Table 6a). The smallest maize yield in Dombe $\left(1.5 \mathrm{t} \mathrm{ha}^{-1}\right.$, Farm type $\left.3 \mathrm{~b}\right)$ was comparable to the second largest maize yield in Zembe (1.7 $\mathrm{t} \mathrm{ha}^{-1}$, Farm type 2$)$. The difference in maize yield between the Posts was much wider for Farm types $3 \mathrm{a}\left(0.7 \mathrm{t} \mathrm{ha}^{-1}\right)$ and for Farm type $3 \mathrm{~b}\left(0.4 \mathrm{t} \mathrm{ha}^{-1}\right)$. For Farm type 1 the difference was $\left(0.3 \mathrm{tha}^{-1}\right)$ and for Farm types 2 it was only $\left(0.2 \mathrm{tha}^{-1}\right)$. Farm type 1 had better maize yields in both Posts (Table 7), which can mainly be attributed to timely weeding, achieved by hiring labour. Farm types 3a and $3 \mathrm{~b}$ in Zembe had very poor maize yields and labour productivity was poor compared with the other farm types. The larger maize yields in Farm type 1 in Dombe than in Zembe are due to the combination of better soils (Table 3 ) and better crop management. The maize labour productivity for Farm type 1, however, was similar in Zembe and Dombe, due to lower labour inputs in Zembe. For the other farm types the labour productivity was higher in Dombe than in Zembe. Sunflower yields were similar across all farm types (including Farm type 1), except for Farm type 3a where yields were lower (Table $6 \mathrm{~b}$ ). Labour productivity tended to be highest in Farm type 1. The yield of improved sesame (Farm type 1) was slightly larger but the labour input almost twice that of 
Table 5 Distribution of households over farm types and household characteristics per site (S) and per farm type (FT) for Zembe and Dombe based on the rapid farm survey

\begin{tabular}{|c|c|c|c|c|c|c|c|c|c|c|c|c|c|c|c|}
\hline \multirow{2}{*}{$\begin{array}{l}\text { Sites (S) } \\
\text { Variables }\end{array}$} & \multirow[b]{2}{*}{ unit } & \multicolumn{4}{|c|}{$\begin{array}{l}\text { Zembe }(\mathrm{n}=52) \\
\text { Farm types }(\mathrm{FT})\end{array}$} & \multirow[b]{2}{*}{ Mean } & \multirow[b]{2}{*}{$\mathrm{P}(\mathrm{FT})^{\mathrm{w}}$} & \multicolumn{6}{|c|}{$\begin{array}{l}\text { Dombe }(\mathrm{n}=72) \\
\text { Farm types }(\mathrm{FT})\end{array}$} & \multicolumn{2}{|c|}{ P-values ${ }^{y}$} \\
\hline & & 1 & 2 & $3 a$ & $3 b$ & & & 1 & 2 & $3 a$ & $3 b$ & Mean & $\mathrm{P}(\mathrm{FT})^{\mathrm{w}}$ & S & FT \\
\hline Distribution of households & $\%$ & 17 & 44 & 15 & 23 & & & 24 & 31 & 31 & 15 & & & & \\
\hline Cultivated area & ha & $2.2^{\mathrm{a}}$ & $1.2^{\mathrm{b}}$ & $0.9^{\mathrm{c}}$ & $0.7^{\mathrm{c}}$ & 1.2 & 0.000 & $4.4^{\mathrm{a}}$ & $1.9^{\mathrm{b}}$ & $1.1^{\mathrm{c}}$ & $1.0^{\mathrm{c}}$ & 2.1 & 0.000 & $<0.000$ & $<0.000$ \\
\hline Household size & $\# \mathrm{hh}^{-1}$ & $8.1^{\mathrm{a}}$ & $5.4^{\mathrm{b}}$ & $4.9^{\mathrm{b}}$ & $4^{b}$ & 5.5 & 0.002 & $9.8^{\mathrm{a}}$ & $7.3^{\mathrm{ab}}$ & $6.8^{\mathrm{b}}$ & $5.2^{\mathrm{b}}$ & 7.4 & 0.002 & 0.001 & $<0.000$ \\
\hline Household labourers $^{\mathrm{u}}$ & $\# \mathrm{hh}^{-1}$ & $3.8^{\mathrm{a}}$ & $3.7^{\mathrm{b}}$ & $3.1^{\mathrm{b}}$ & $2.6^{\mathrm{b}}$ & 3.3 & 0.005 & $4.2^{\mathrm{a}}$ & $3.8^{\mathrm{b}}$ & $3.8^{\mathrm{b}}$ & $3.2^{\mathrm{b}}$ & 3.9 & 0.002 & 0.051 & 0.000 \\
\hline Land:labour ratio (LLR) ${ }^{\mathrm{v}}$ & ha person ${ }^{-1}$ & $0.6^{\mathrm{a}}$ & $0.4^{\mathrm{b}}$ & $0.3^{\mathrm{b}}$ & $0.3^{\mathrm{b}}$ & 0.4 & 0.001 & $0.8^{\mathrm{a}}$ & $0.5^{\mathrm{b}}$ & $0.3^{\mathrm{c}}$ & $0.4^{\mathrm{bc}}$ & 0.5 & 0.000 & 0.003 & $<0.000$ \\
\hline Female headed households & $\%$ & $0^{\mathrm{a}}$ & $17^{\mathrm{b}}$ & $50^{\mathrm{b}}$ & $58^{\mathrm{b}}$ & - & 0.008 & $12^{\mathrm{a}}$ & $17^{\mathrm{a}}$ & $27^{\mathrm{a}}$ & $27^{\mathrm{a}}$ & - & 0.621 & 0.304 & $0.025^{\mathrm{z}}$ \\
\hline Chickens $^{\mathrm{u}}$ & $\# \mathrm{hh}^{-1}$ & $26.0^{\mathrm{a}}$ & $14.0^{\mathrm{a}}$ & $13.0^{\mathrm{a}}$ & $5.0^{\mathrm{b}}$ & 13.8 & 0.007 & $27.0^{\mathrm{a}}$ & $18.0^{\mathrm{ab}}$ & $12.0^{\mathrm{b}}$ & $10.0^{\mathrm{b}}$ & 16.9 & 0.039 & 0.330 & $<0.008$ \\
\hline Cattle $^{\mathrm{u}}$ & $\# \mathrm{hh}^{-1}$ & $2.4^{\mathrm{a}}$ & $0.3^{\mathrm{b}}$ & $0^{\mathrm{b}}$ & $0^{\mathrm{b}}$ & 0.6 & 0.000 & $2.2^{\mathrm{a}}$ & $0^{\mathrm{b}}$ & $0.5^{\mathrm{b}}$ & $0.3^{\mathrm{b}}$ & 0.7 & 0.004 & 0.731 & 0.000 \\
\hline Goats $^{\mathrm{u}}$ & $\# \mathrm{hh}^{-1}$ & $4.7^{\mathrm{a}}$ & $1.6^{\mathrm{ab}}$ & $1.5^{\mathrm{a}}$ & $0.3^{\mathrm{b}}$ & 1.8 & 0.067 & $5.9^{\mathrm{a}}$ & $6.0^{\mathrm{ab}}$ & $2.3^{\mathrm{bc}}$ & $1.3^{\mathrm{c}}$ & 4.2 & 0.039 & 0.009 & 0.005 \\
\hline
\end{tabular}

${ }^{\mathrm{a}, \mathrm{b}, \mathrm{c}}$ Means followed by the same superscript letter in a row do not differ significantly as assessed by the Tukey HSD and the Mann-Whitney Tests

${ }^{\mathrm{u}}$ Calculated based on rank using Kruskal-Wallis test

${ }^{\mathrm{v}}$ LLR is calculated as the cultivated area per household labourer, taking into account children $<12$ year as $1 / 4$ labourer and excluding hired labour

${ }^{\mathrm{w}} \mathrm{p}(\mathrm{FT})$ is the probability for farm types in each site

${ }^{\mathrm{y}}$ Probability value for the site and farm type comparison

${ }^{\mathrm{z}}$ Probability value for farm type comparison only

traditional varieties (Farm types 2, 3a and 3b) (Table 6b). This was because the improved sesame varieties were grown as sole crops, demanding labour for land preparation, whereas the traditional varieties were relay-intercropped into the maize fields. No labour was hired for cultivation of cash crops.

The hiring-out of labour from Farm type $3 \mathrm{~b}$ caused severe reductions in both land and labour productivity as weeding of their own fields was delayed. Thus although the early cropping season offers the greatest opportunity in the year to find work (paid in kind or cash), a strong trade-off existed between hiringout labour and focusing on cropping in their own fields.

In Dombe the land productivity, expressed in economic value per ha (Table 7), was larger for maize-sesame relayintercropping with traditional varieties in Farm types 2-3b, than for maize and sesame as sole crops in Farm type 1. Farm type 2 had only slightly greater land productivity than $3 \mathrm{a}$ and b. For maize-sunflower the land productivity was greater in Farm types 1 and 2 than in Farm types $3 a$ and $b$.

Maize yields of all farm types in both Posts were above the estimated provincial and national averages of 0.5 and $0.6 \mathrm{t} \mathrm{ha}^{-1}$, respectively. Yet they were far below the attainable yields of $6.0 \mathrm{t} \mathrm{ha}^{-1}$ obtained with the use of fertilizers at a nearby research station (Geurts and Van den Berg 1998) indicating a large yield gap. In general, sunflower yields were small (Table 6b) compared with the average yields in Manica province of $0.6 \mathrm{tha}^{-1}$ which can be explained by the sparse plant density $\left(15,870\right.$ plants $\mathrm{ha}^{-1}$ measured in relay-intercropping compared with the recommended density of about 50,000 plants $\mathrm{ha}^{-1}$ in monoculture), as well as lack of fertilizer use. In Dombe, the yield of sesame in all farm types was larger than the average yield of $0.4 \mathrm{tha}^{-1}$ estimated for Manica province. The land productivity, expressed in terms of the economic value per ha (Table 7), showed that growing maize and sesame in relay-intercropping earned 50-70\% more than growing sole crops of maize and the improved sesame variety under current management. This was also reflected in the labour productivity, as sesame as a sole crop requires more labour, particularly for land preparation. Our results on time spent in performing the agricultural activities are in agreement with other studies in the region. For instance, Howard et al. (1998) found that households in East and Central Manica spent 620 to 990 manhours $\mathrm{ha}^{-1}$ cultivating maize. Values of the same magnitude were also reported by Uaiene (2004).

\section{Maize self-sufficiency at farm level}

The food self-sufficiency ratio based on maize as proxy indicator showed that all farm types produced enough maize to satisfy household consumption needs year-round, except Farm type $3 \mathrm{~b}$ in Zembe (Table 8 ). Farm type $3 \mathrm{~b}$ in Zembe was not self-sufficient due to low maize yields in combination with the small area cultivated. Although Farm type 3a cultivated the same area as Farm type 3b, the sharing of labour during the weeding phase (gúmuè) seemed to improve the maize yield sufficiently to enable Farm type 3 a to achieve self-sufficiency. The average income from hiring out labour

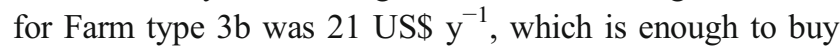
$100 \mathrm{~kg}$ of grain maize in the local market. When this amount of maize was added to the total maize production, Farm type $3 \mathrm{~b}$ was just self-sufficient as was Farm type 3a. Farm type $3 \mathrm{~b}$ 
Fig. 4 Crop labour calendars for the cultivation of maize, sunflower and sesame for different farm types (FT) in Zembe and Dombe. The dashed line indicates the total available labour in the whole farm based on both adult and children's input with long days due to time pressure on activities. The lower available labour corresponding to labour used during land preparation excludes children because they do not participate in land preparation

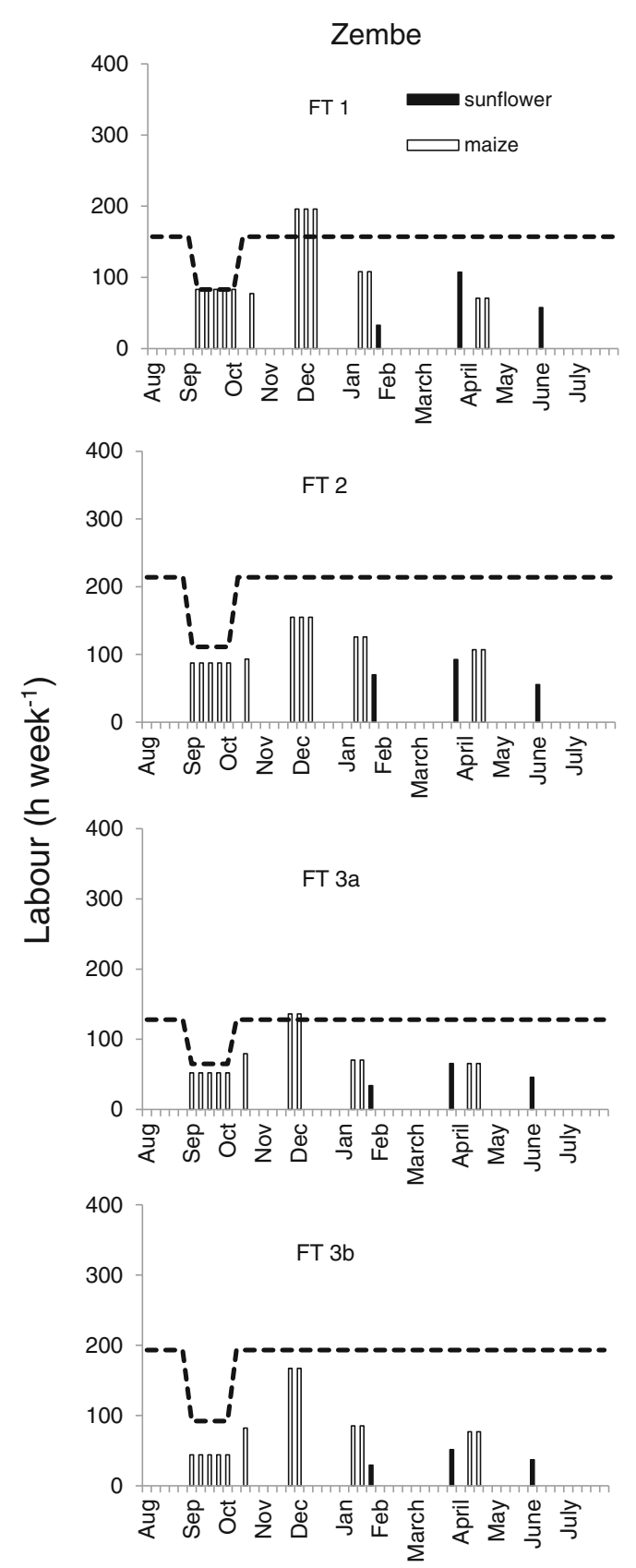

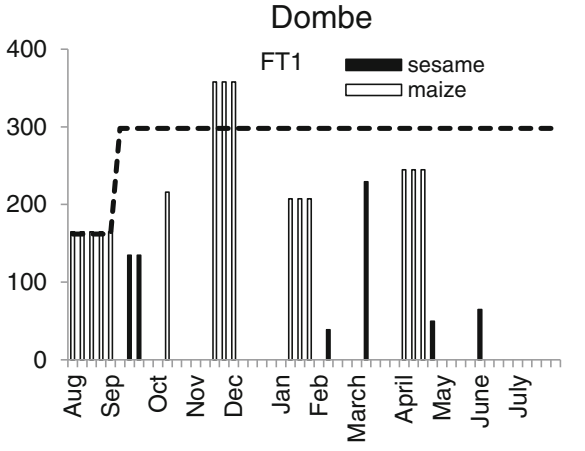
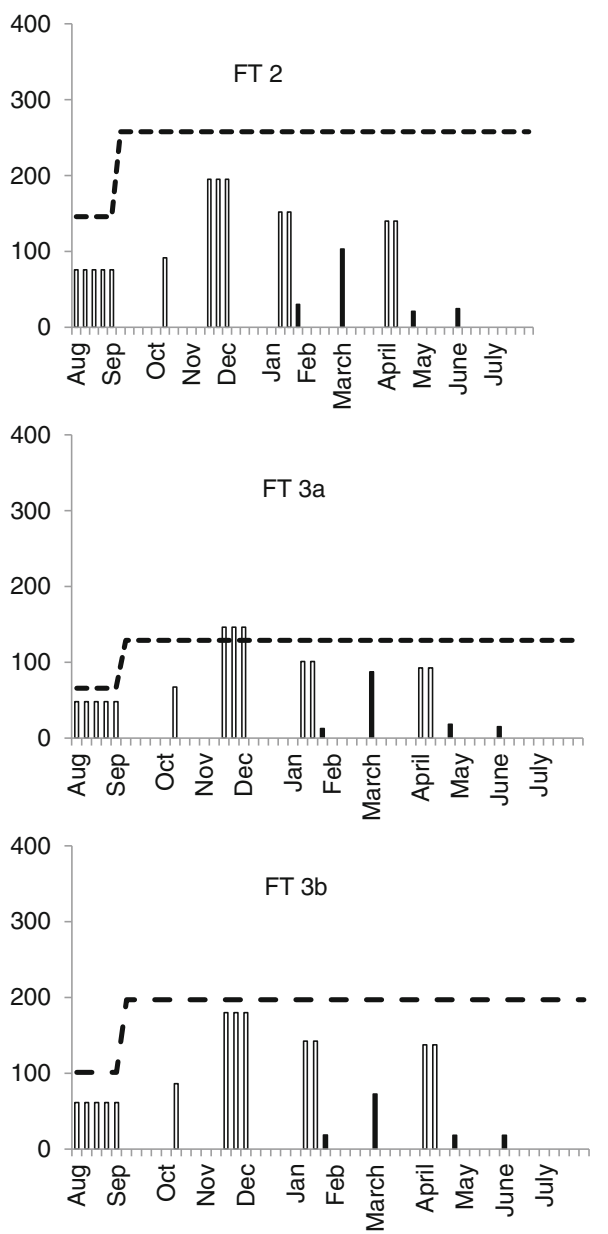

could become maize self-sufficient by working on their own farms, but this would prevent them from earning food and cash through selling their mutrakita labour during a critical period when their own food stocks are exhausted.

Surpluses were sold at the market or used for paying labour in kind. Farm type 1 in Zembe and all farm types in Dombe produced maize for sale in the market. Farm type 2 in Zembe only sold maize when there was sufficient surplus. The results do not take into account harvest losses nor post-harvest losses as it was not possible to verify these. So, we may have overestimated the food self-sufficiency of the various farm households. According to the agricultural census (TIA) $16 \%$ of households in Manica reported post-harvest losses, $61 \%$ of which reported insect pests as the major problem. Post-harvest losses due to the larger grain borer (LGB) are severe in the neighbouring province of Gaza (Milgroom and Giller 2013).

\section{Land and labour productivities at farm level}

Land productivity (Eq. 1), as expressed in revenues from crop production was higher in Dombe than in Zembe for all farm types (Fig. 7). Farm type 1 had the greatest land productivity in both Posts (2840 US\$ y ${ }^{-1}$ in Dombe) and (880 US\$ y ${ }^{-1}$ in Zembe). In both Posts, the revenues decreased in the order Farm types 1, 2, 3a and 3b. Maize contributed more to total land productivity of the larger farms than the crops grown 
Table 6 Cultivated area, labour use per hectare, crop yields and labour productivities, total labour input and hired labour at farm level for maize (a), sunflower and sesame (b) for different farm types based on the detailed survey ( $n=2$ for Farm type 1 and $n=3$ for other farm types)

\begin{tabular}{|c|c|c|c|c|c|c|c|c|c|}
\hline \multirow{2}{*}{$\begin{array}{l}\text { Sites } \\
\text { Variables }\end{array}$} & \multirow[b]{2}{*}{ Unit } & \multicolumn{4}{|c|}{$\begin{array}{l}\text { Zembe } \\
\text { (Farm types) }\end{array}$} & \multicolumn{4}{|c|}{$\begin{array}{l}\text { Dombe } \\
\text { (Farm types) }\end{array}$} \\
\hline & & 1 & 2 & $3 a$ & $3 b$ & 1 & 2 & $3 a$ & $3 b$ \\
\hline (A) & & \multicolumn{4}{|c|}{ Maize } & \multicolumn{4}{|c|}{ Maize } \\
\hline Cultivated area & ha & 2.1 & 1.5 & 0.8 & 0.8 & 3.4 & 1.9 & 1.3 & 1.3 \\
\hline Total labour & $\mathrm{h} \mathrm{ha}^{-1}$ & 750 & 990 & 980 & 1270 & 930 & 880 & 870 & 1140 \\
\hline Maize yield & $\mathrm{t} \mathrm{ha}^{-1}$ & 2.0 & 1.7 & 1.1 & 1.1 & 2.3 & 1.9 & 1.8 & 1.5 \\
\hline Maize labour productivity $\left(10^{-3}\right)$ & $\mathrm{th}^{-1}$ & 2.6 & 1.7 & 1.2 & 0.9 & 2.5 & 2.1 & 2.0 & 1.4 \\
\hline Total labour ${ }^{\mathrm{a}}$ & $\mathrm{h}$ farm $^{-1}$ & 1530 & 1460 & 880 & 960 & 3160 & 1640 & 1130 & 1490 \\
\hline Hired labour & $\mathrm{h}$ farm $^{-1}$ & 140 & 25 & 0 & 0 & 130 & 10 & 0 & 0 \\
\hline (B) & & \multicolumn{4}{|c|}{ Sunflower } & \multicolumn{4}{|c|}{ Sesame } \\
\hline Cultivated area & ha & 1.4 & 1.0 & 0.4 & 0.4 & 1.0 & 0.6 & 0.4 & 0.4 \\
\hline Total labour & $\mathrm{h} \mathrm{ha}{ }^{-1}$ & 150 & 230 & 330 & 330 & 640 & 320 & 330 & 340 \\
\hline Crop yield & $\mathrm{t} \mathrm{ha}^{-1}$ & 0.3 & 0.3 & 0.2 & 0.3 & 1.3 & 1.0 & 0.9 & 0.9 \\
\hline Crop labour productivity $\left(10^{-3}\right)$ & $\mathrm{th}^{-1}$ & 1.7 & 1.1 & 0.5 & 0.8 & 2.0 & 3.2 & 2.7 & 2.6 \\
\hline Yield & $\mathrm{t}$ farm $^{-1}$ & 0.3 & 0.2 & 0.1 & 0.1 & 1.5 & 0.7 & 0.4 & 0.4 \\
\hline Total labour ${ }^{\mathrm{a}}$ & $\mathrm{h}$ farm $^{-1}$ & 200 & 230 & 130 & 120 & 640 & 180 & 130 & 130 \\
\hline Hired labour & $\mathrm{h}$ farm $^{-1}$ & 0 & 0 & 0 & 0 & 0 & 0 & 0 & 0 \\
\hline
\end{tabular}

${ }^{a}$ Includes household and hired in labour

solely for cash. In Dombe, sesame contributed $40-45 \%$, of the land productivity while in Zembe sunflower contributed only $10-15 \%$, as both price and yield of sunflower were low.

Also, labour productivity (Eq. 2), expressed in revenues per hour of labour input, was greater in Dombe than in Zembe for all farm types. Farm type 1 had a revenue of $0.53 \mathrm{USS} \mathrm{h}^{-1}$ in Zembe and 0.74 US\$ $\mathrm{h}^{-1}$ in Dombe mainly due to the high contribution of sesame compared with sunflower. In Zembe labour productivity at farm level was similar for Farm types 3a and 3b, i.e., $0.18 \mathrm{US}^{-1}$. In Dombe the labour productivity decreased in the same order. The contribution of maize to labour productivity in Dombe was similar to that in Zembe for all of the farm types, but cultivating sesame doubled the labour productivity of farmers in Dombe (Fig. 7). This was also observed on Farm type 1 despite the low productivity of cultivating sesame as a sole crop due to the extra labour needed for land preparation in this farm type.

Our calculations indicated that the amount of labour available on the poorer farms was not limiting for crop production even during peak periods (except for Farm type 3 a in Dombe), which led us to hypothesise that the quality of labour might be affected by alcohol consumption (Fig. 4). Heads of

Fig. 5 Percentage of households without an additional source of income; with one source of income from a temporary job or permanent job or petty trade; and with two or three sources of income simultaneously

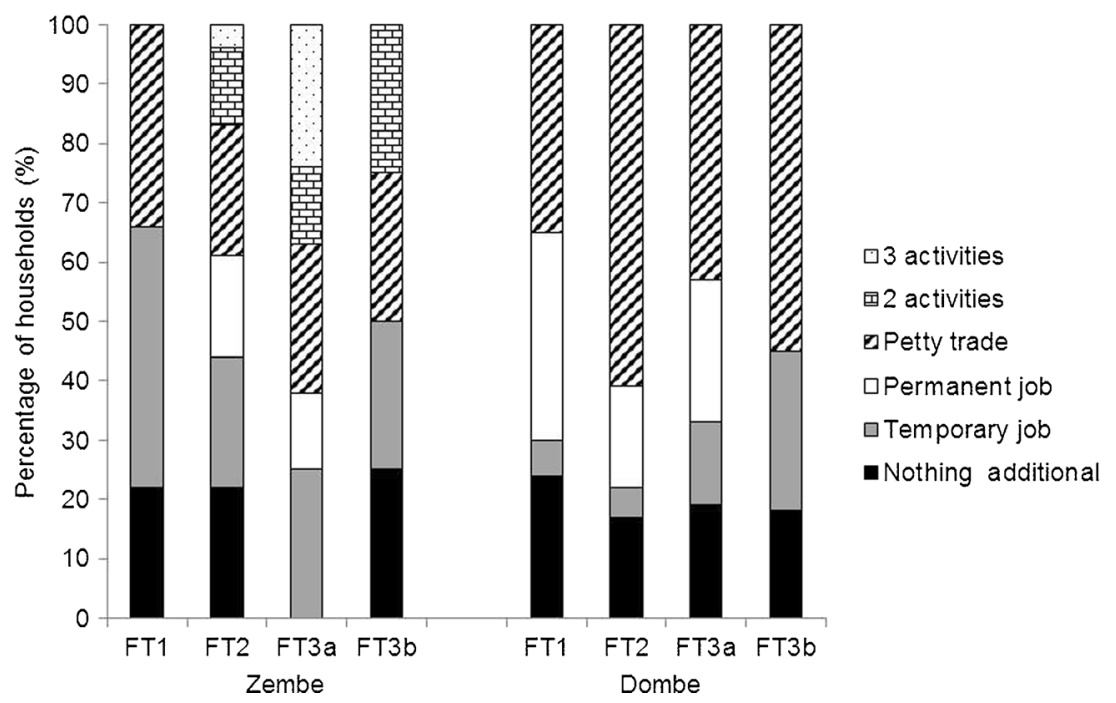


Table 7 Land productivity of maize, sesame sunflower in sole cropping and relay-intercropping systems in Dombe village, based on farm gate prices at harvesting time

\begin{tabular}{|c|c|c|c|c|c|c|c|c|c|}
\hline \multirow[t]{2}{*}{ Variables } & \multirow[t]{2}{*}{ Unit } & \multicolumn{4}{|c|}{ Dombe (Farm types) } & \multicolumn{4}{|c|}{ Zembe (Farm types) } \\
\hline & & $1^{\mathrm{a}}$ & $2^{\mathrm{a}}$ & $3 a^{a}$ & $3 b^{a}$ & $1^{\mathrm{b}}$ & $2^{\mathrm{c}}$ & $3 a^{c}$ & $3 b^{c}$ \\
\hline Maize yield & $\mathrm{tha}^{-1}$ & 2.0 & 1.7 & 1.1 & 1.1 & 2.3 & 1.9 & 1.8 & 1.7 \\
\hline Sesame yield & $\mathrm{tha}^{-1}$ & - & - & - & - & 1.3 & 1.0 & 0.9 & 0.9 \\
\hline Sunflower yield & $\mathrm{tha}^{-1}$ & 0.3 & 0.3 & 0.2 & 0.3 & - & - & - & - \\
\hline Land productivity & US\$ ha ${ }^{-1}$ & 413.7 & 373.2 & 250 & 267.6 & 698.2 & 1122.9 & 997.2 & 990.5 \\
\hline
\end{tabular}

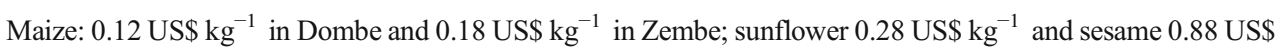
$\mathrm{kg}^{-1}$

${ }^{a}$ Maize and sunflower in relay-intercropping

${ }^{\mathrm{b}}$ Maize and sesame both as sole crops in a rotation, land productivity is the average per ha maize or sesame

${ }^{\mathrm{c}}$ Maize and sesame in relay- intercropping system households that belonged to Farm type 1 consumed significantly $(P=0.001)$ less alcohol than household heads of the other farm types. Averaging breath alcohol contents for both Posts gave $0.2 \%$ for Farm type 1, 1.1\%o for Farm type 2, 1.5\% for Farm type 3a and 1.6\%o for Farm type 3b (Fig. 6). No differences were observed between male and female household heads in breath alcohol contents.

The intermediate and smaller farms had average values above the legal threshold for driving of $0.6 \%$, suggesting that the quality of their labour might be impaired. While the selling of alcohol by these farmers in Posts could be seen as an important off-farm activity, it may contribute to the low productivity of these poorer farmers. Lawson et al. (2006) pointed out that alcohol abuse was one of key factors for persistent poverty in Uganda. Tellegen (1997) cited by Bryceson (1999) showed that alcohol consumption in the agricultural production sector tended to divert resources from productive investment. Whether excessive alcohol consumption is due to poverty (Khan et al. 2002) or poverty results from alcohol consumption is open to debate.

Table 9 shows the prices for maize and the amounts sold in the different seasons. Prices in the lean season were higher due to scarcity. The need for cash determined when farmers sold their maize. In Zembe all farm types sold part of their maize just after harvest and some farms in Farm types $3 \mathrm{a}$ and $\mathrm{b}$ sold everything they produced. Farm type 1 and 2 were able to benefit from the higher prices during the lean season, although the price difference was small compared with Dombe: in Zembe the price increased by $20 \%$ and in Dombe by $130 \%$ between harvest time and the lean season. In Dombe only Farm type 1 was able to sell maize in the lean season and sold none just after harvest. Sales from Farm types 2-3b were evenly spread over the harvest period and the middle season.

In Manica, the per capita poverty line was estimated to be 0.68 US\$ per day (Alfani et al. 2012) well below the international values of US\$ 1.0 or US\$ 1.25 . If households fully relied on agriculture for their income, the average remuneration in Zembe would be 1.0, 0.39, 0.28 and 0.14 US\$ per person per day for Farm types 1, 2, 3a and 3b, respectively. In Dombe, the remuneration was higher than in Zembe, i.e., $1.48,0.67,0.77$ and 0.49 US\$ per day for Farm types 1, 2, 3a and $3 \mathrm{~b}$, respectively. This indicates that in Zembe other activities are more important than in Dombe. The dashed lines in Fig. 7 show the minimum annual revenue (a) and minimum wage (b) based on minimum national wage for the farming sector in Mozambique (Moçambique 2012).

The remuneration for labour in Dombe indicated that producing and selling their own crops is more financiallyattractive than being employed in the farming sector in Mo-

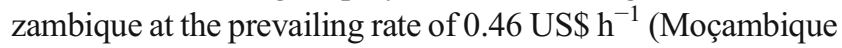
2012), except for Farm type 3b. Over a full year, all farm types in Zembe had annual land revenue below the minimum for the farming sector in Mozambique.

Comparison of farm revenue per labourer with consumption per capita per day in (US\$) provided a similar picture as remuneration per hour invested in the farm. All farm types in Zembe were below the poverty line, except Farm type 1. In Dombe, only Farm type $3 \mathrm{~b}$ was below the poverty line.
Table 8 Maize food selfsufficiency ratio per farm type in Zembe and Dombe based on the detailed survey $(n=2$ for Farm type 1 and $n=3$ for other farm types)

\begin{tabular}{|c|c|c|c|c|c|c|c|c|c|}
\hline \multirow{2}{*}{$\begin{array}{l}\text { Sites } \\
\text { Variables }\end{array}$} & \multirow[b]{2}{*}{ Unit } & \multicolumn{4}{|c|}{ Zembe (Farm types) } & \multicolumn{4}{|c|}{ Dombe (Farm types) } \\
\hline & & 1 & 2 & $3 \mathrm{a}$ & $3 b$ & 1 & 2 & $3 a$ & $3 b$ \\
\hline Household size & \# & 5 & 7 & 7 & 6 & 10 & 7 & 5 & 6 \\
\hline Household need & ${\mathrm{t} \mathrm{yr}^{-1}}^{-1}$ & 0.9 & 1.1 & 1.1 & 0.9 & 1.1 & 1.2 & 0.9 & 1.2 \\
\hline Total yield & ${\mathrm{t} \mathrm{yr}^{-1}}^{-1}$ & 4.1 & 2.6 & 1.0 & 0.8 & 7.7 & 3.6 & 2.3 & 2.2 \\
\hline Food self-sufficiency & & 4.6 & 2.4 & 1.0 & 0.9 & 6.6 & 3.0 & 2.6 & 1.8 \\
\hline
\end{tabular}



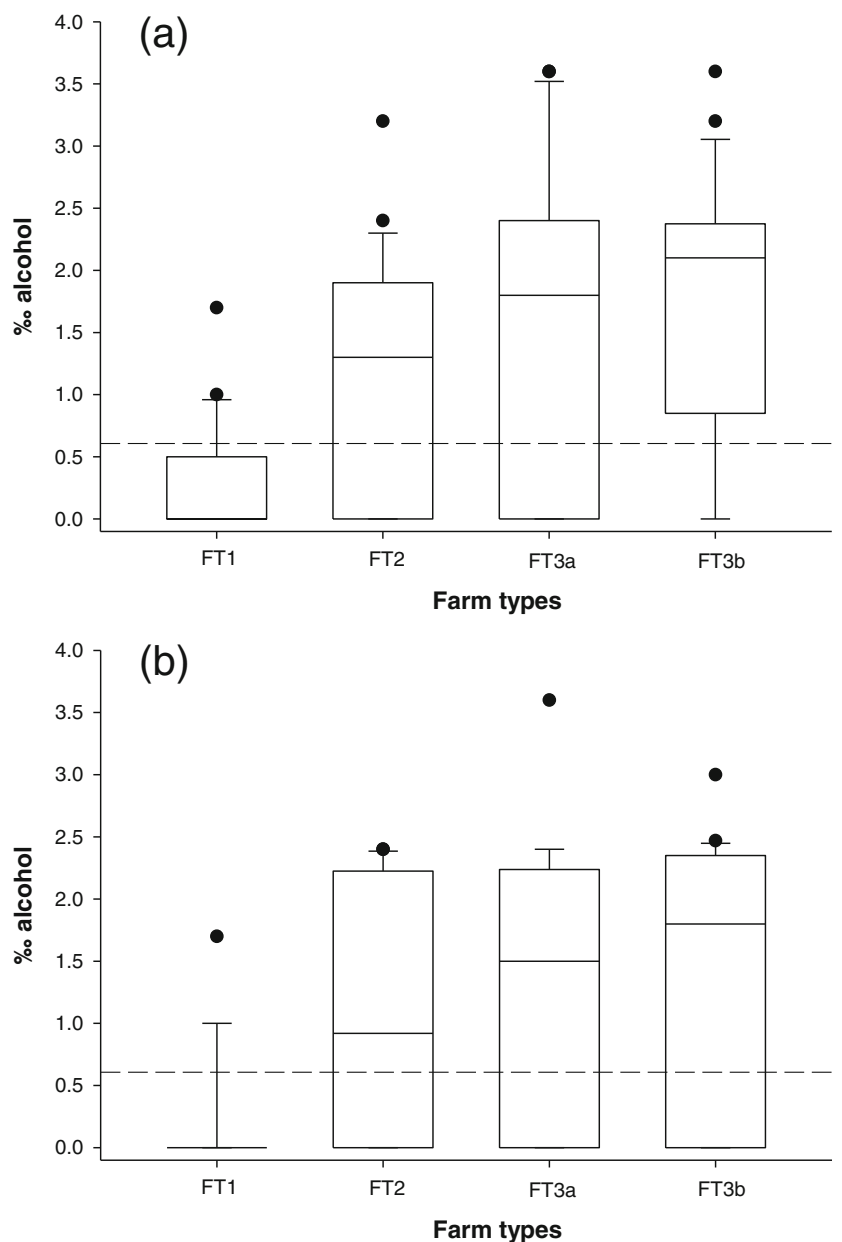

Fig. 6 Breath alcohol content (\%) for different farm types in Zembe (a) and Dombe (b) based on a total sample of $n=176$. The box-and-whisker plots show five statistics - the minimum, the lower quartile, the median, the upper quartile, the maximum. The black dots at the upper end of the box are outliers. The box contains the middle $50 \%$ of data values. The line drawn across the box is the sample median for each farm type. The dashed horizontal line indicates the blood alcohol content limit above which it is illegal to drive in Mozambique

Household members from all types of farms engaged in temporary jobs outside agriculture such as road construction, petty trade and self-employment (Fig. 5). They also sold charcoal, firewood or chickens in their village market or in Chimoio. Chickens were the most common source of extra income. We did not assess the revenues from those other activities, and smallholder farmers access food in a variety of ways (Ellis 2000; Eriksen and Silva 2009; Hahn et al. 2009). The other activities were more important for livelihood support in Zembe than in Dombe. Zembe is located at a relatively short distance from the main urban market (Chimoio) compared with Dombe. Therefore, farmers in Zembe benefit more from off-farm opportunities, which make them less dependent on agriculture. Off-farm income opportunities were particularly important for the small farms. Jones and Tarp (2012) highlighted the need of employment opportunities outside the agricultural sector in Mozambique as a means of breaking out of the poverty trap for smallholder farmers.

During our focus group discussions, we observed that perceptions on land and labour productivity varied across farmer types. For instance, among the farmers with larger farms (Farm type 1), those with smaller farms (Farm type 3a and 3b) were seen as people who were not fully committed to farming. To quote a few of them "the smaller farmers have smaller yields than we do because they don't plan their activities on time. They do everything in a rush. Some of them are always drunk and lazy - we see this when they are working for us!" Farm type 1, Dombe, 2012 focus group discussion. The small-scale farmers, however, see themselves as "trapped in poverty" as can be inferred from the following quote "We own lands but small fields; we go and work for larger farmers; we need this money to do milling, buy soap, salt. Where do we go for cash when our children are sick? We don't have chickens or goats like large farmers to sell!" Farm type 3b, Zembe 2012, focus group discussion.

Alwang and Siegel (1999) reported a similar situation with regard to the sale of casual labour by smallholders during peak periods in Malawi, which contributed to poor returns to land and labour. Yet, a further analysis of income from hiring out labour showed that it can leverage the maize needed and allow Farm type 3a to achieve food security. As mentioned, we noticed excessive alcohol consumption among Farm types $3 \mathrm{a}$ and $3 \mathrm{~b}$ which also presumably impacted their ability to earn income from selling their labour.

\section{Opportunities to increase overall productivity}

All current farming systems depend on fallow land to sustain crop production. Jones and Tarp (2012) identified lack of
Table 9 Variation in the price of maize and the proportion of total surplus sold at different periods of agricultural season by different farm types at in Zembe and Dombe based on the detailed survey

\begin{tabular}{|c|c|c|c|c|c|c|c|c|c|c|}
\hline \multirow[b]{3}{*}{ Period } & \multirow[b]{3}{*}{ Prices (US\$ kg ${ }^{-1}$ ) } & \multicolumn{9}{|c|}{ Percentage sold per farm type $(\%)$} \\
\hline & & \multicolumn{5}{|c|}{ Zembe (Farm types) } & \multicolumn{4}{|c|}{ Dombe (Farm types) } \\
\hline & & 1 & 2 & $3 a$ & $3 b$ & Prices (US\$ kg ${ }^{-1}$ ) & 1 & 2 & $3 a$ & $3 b$ \\
\hline Harvest period & $0.18(0.14-0.21)$ & 20 & 50 & 100 & 100 & $0.12(0.11-0.14)$ & 0 & 40 & 60 & 60 \\
\hline Middle season & $0.19(0.18-0.21)$ & 30 & 30 & 0 & 0 & $0.23(0.18-0.28)$ & 70 & 60 & 40 & 40 \\
\hline Lean season & $0.21(0.21-0.21)$ & 50 & 20 & 0 & 0 & $0.28(0.25-0.32)$ & 30 & 0 & 0 & 0 \\
\hline
\end{tabular}

In parentheses is the range of values from which the average price was calculated. 
Fig. 7 Land (a) and labour (b) productivity of maize, sesame and sunflower at farm scale for all farm types in both administrative Posts. The dashed horizontal lines indicates (a) the minimum annual revenue (b) the minimum wage per hour for farming sector in Mozambique

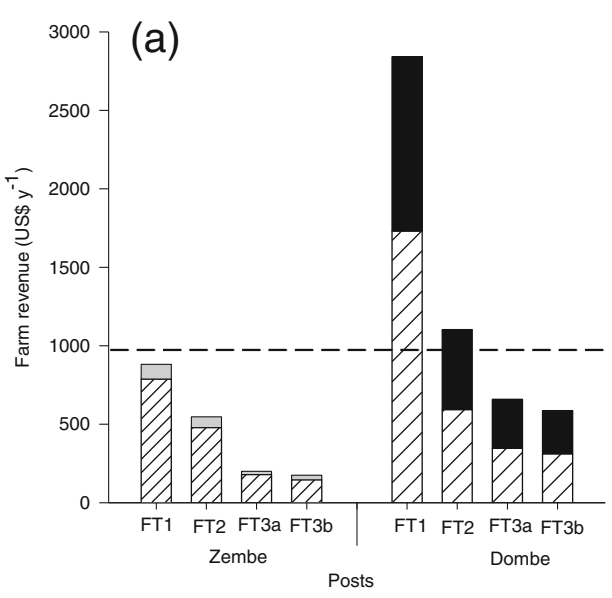

fertilizer use as a major reason for poor crop yields in Mozambique. In Zembe and Dombe, the better-endowed farmers have the best opportunities to use external inputs such as fertilizers. Type 1 farms cultivated an improved sesame variety, indicating some purchasing power. They also needed cash or maize to pay hired labour for weeding as they had relatively more land and they were able to use animal traction. If the use of animal traction could be extended to weeding, this would free labour during the most labour-constrained period, leading to opportunities for the larger-scale farmers to extend their land area and for the smaller-scale farmers to work on their own fields or on other activities.

For Farm types 2, 3a and 3b with little purchasing power, intercropping with legume crops seems to be one of the few options to enhance productivity. For instance, maizepigeonpea intercropping systems in Ruaca (only $30 \mathrm{~km}$ from Zembe) supported maize yields of 5.6 ton $\mathrm{ha}^{-1}$ without fertilizers (Rusinamhodzi et al. 2012). One emerging crop in the country, and in particular in Manica Province, is soybean, driven by huge demand for feed from the poultry industry in urban centres (FAO 2013). Soybean offers opportunities for the farmers to increase income and improve soil fertility. However, a further analysis is needed on the economic benefits of sunflower and sesame as opposed to or in addition to pigeonpea and soybean.

The location and agro-ecological characteristics of the Posts offer different pathways for improvement. In Dombe soils were better and hence yields were higher. We observed buyers using helicopters and large trucks to purchase maize for the market in the central and southern regions of Mozambique, pointing to the importance of the maize market in Dombe, despite the longer distance from a major city such as Chimoio. Most of the farmers sell maize individually and in small quantities. Cooperating in sales activities could offer them a better bargaining position (Markelova et al. 2009; Kirsten and Sartorius 2002). Currently, only $17 \%$ of the farmers are affiliated with associations in Dombe. In Zembe soils were less fertile, yields were poorer and no such associations exist. The proximity to Chimoio market allowed farmers to transport their own produce to the market by bicycle and more non-agricultural activities for income generation were practised.

Poor soil fertility is considered the fundamental constraint to productivity of smallholder farmers in sub-Saharan Africa (Sanchez et al. 1997; Stoorvogel et al. 1993; Folmer et al. 1998). This was clearly not the case in this region of Mozambique, which can be considered a fairly typical area with good agricultural potential and abundant land. Farmers in both Posts, in particular those in Dombe, cultivate as much land as possible with the labour available in order to have greater production instead of investing in yield increasing technologies such as fertilizers. These findings are in agreement with those of Baudron et al. (2012) who indicated that smallholder farmers tend to move towards extensification rather than intensification if land is abundant. Another possible reason is the relatively high price of fertilizers in Mozambique - nearly twice those of its neighbouring countries such as Malawi and Zimbabwe (Benson et al. 2012). Opportunities for intensification exist, especially for larger farms, but then financial resources for external inputs or labour saving technologies (e.g. machinery) are required (Udo et al. 2011). In situations where labour-intensive innovations are not adopted, shortage of labour is often the main limiting factor for production (Woodhouse 2010).

The result showed that in order to increase smallholder productivity, the main objective of the PEDSA, CAADP and NEPAD, heterogeneity of smallholder farmers within and across regions must be acknowledged. Different farm types require different technologies. In addition, partial introduction of a new technology did not lead to improvements for rural livelihoods, e.g. using improved sesame varieties without fertilizer resulted in lower labour productivity and using cattle without the availability of a cultivator did not relieve labour constraints in the most critical period.

Our results also suggest that poverty alleviation may not be built on agriculture alone, especially for the smaller-scale 
farmers who are trapped in poverty. Off-farm jobs in large scale agriculture (such as biofuel plantations) or other industries could potentially provide an escape route.

\section{Conclusions}

Overall our study highlights the importance of addressing labour productivity rather than land. The results paint a rather depressing picture of a vicious cycle of poverty for about $40 \%$ of smallholder farmers in this area of relatively high agricultural potential in Mozambique. All of the smallholder farms were food self-sufficient in maize, except for the poorest farmers (Farm type 3b) in Zembe. At farm level, maize provided more revenue to the household than sunflower and sesame. Overall revenues from sunflower were very poor. Access to labour during first weeding was the main factor determining crop yields. Large farms were able to hire in extra labour from small farms to weed in time and ensure relatively good yields. The small farms hired out their labour during that period at the expense of the yields of their own fields. They were forced to do so due to lack of food and cash stocks. In addition, they had to sell their maize in the period of low market prices i.e. at harvest. Together, these factors keep the poorest farmers trapped in poverty.

Our study has shown that to increase productivity of smallholder farmers there is a clear need to understand the diversity of farms and farmers' social and economic context. For large farms two development pathways exist: to increase production per ha (intensification) and to increase the area of land (extensification). For intensification, yield increasing measures are required, such as fertilizer application. For extensification, labour saving technologies, such as cultivators and herbicides are required. The large-scale farmers seem to have sufficient resources to choose either pathway. A further exploration is required to assess the impact of both development opportunities. The farm scale analysis suggested that the small farms could improve crop yields by adopting practices related to land and labour use similar to the large farms. However, they were constrained by a lack of labour to use on their own farms as they earned food by working for other farmers, and due to excess consumption of alcohol. For small farms with limited resources, intercropping of maize with soybean could be an opportunity to increase revenues, particularly in Zembe, where revenues are smaller. Given that land is abundant in Mozambique, large-scale capital intensive agriculture, including biofuel plantations or other industries could provide (permanent) off-farm labour opportunities that are more evenly spread throughout the year than only during the weeding period. For the poorer smallholder farmers this could contribute to poverty reduction. Our analysis suggests that the goals of PEDSA, CAADP and NEPAD related to improved agricultural production cannot be achieved without parallel developments in other sectors outside agriculture.

Acknowledgments We are grateful to the farmers for answering the questions, Fernando Manuel in Zembe and Moises Mokoto in Dombe for assistance in collecting data in the field. We thank WOTRO Science for Global Development for funding this work within the integrated programme "Biomass for fuel: opportunity or threat to food and feed security? Case studies for farms in Brazil and Mozambique."

Open Access This article is distributed under the terms of the Creative Commons Attribution 4.0 International License (http:// creativecommons.org/licenses/by/4.0/), which permits unrestricted use, distribution, and reproduction in any medium, provided you give appropriate credit to the original author(s) and the source, provide a link to the Creative Commons license, and indicate if changes were made.

\section{References}

Alfani, F., Azzarri, C., d'Errico, M., \& Molini, V. (2012). Poverty in Mozambique. New evidence from recent household surveys. Policy Rsearch Working Paper 6217 (pp. 33). African Region: The World Bank.

Alwang, J., \& Siegel, P. B. (1999). Labor shortages on small landholdings in Malawi: implications for policy reforms. World Development, 27(8), 1461-1475. doi:10.1016/S0305-750X(99)00065-0.

Barrett, C. B., Reardon, T., \& Webb, P. (2001). Nonfarm income diversification and household livelihood strategies in rural Africa: concepts, dynamics, and policy implications. Food Policy, 26(4), 315 331. doi:10.1016/S0306-9192(01)00014-8.

Batidzirai, B., Faaij, A. P. C., \& Smeets, E. (2006). Biomass and bioenergy supply from Mozambique. Energy for Sustainable Development, 10(1), 54-81.

Baudron, F., Andersson, J. A., Corbeels, M., \& Giller, K. E. (2012). Failing to yield? Ploughs, conservation agriculture and the problem of agricultural intensification: An example from the Zambezi Valley, Zimbabwe. Journal of Development Studies, 48(3), 393-412.

Benson, T., Cunguara, B., \& Mogues, T. (2012). The supply of inorganic fertilizers to smallholder farmers in Mozambique. Evidence for fertilizer policy development. (pp. 40). Washington, DC: The International Food Policy Research Institute.

Bryceson, D. F. (1999). African rural labour, income diversification and livelihood approaches: a long-term development perspective. Review of African Political Economy, 26(80), 171-189. doi:10. 1080/03056249908704377.

Ellis, F. (2000). The determinants of rural livelihood diversification in developing countries. Journal of Agricultural Economics, 51(2), 289-302.

Eriksen, S., \& Silva, J. A. (2009). The vulnerability context of a savanna area in Mozambique: household drought coping strategies and responses to economic change. Environmental Science and Policy, 12, $33-52$.

FAO (2013). Poultry Sector Mozambique. FAO Animal Production and Health Livestock Country Reviews. No. 5. Rome.

FAO-UNESCO (1988). FAO-UNESCO Soil Map of the World. Revised legend. In ISRIC (Ed.), World Soil Resources Report 60. Rome: Food and Agriculture Organization of the United Nations.

Folmer, E. C. R., Geurts, P. M. H., \& Francisco, J. R. (1998). Assessment of soil fertility depletion in Mozambique. In (pp. 159-167): Elsevier Science Bv. 
Geurts, P. M. H., \& Van den Berg, M. (1998). A simple agro-ecological zonation for fertilizer recommendations in Mozambique. Soil Use and Management, 14, 136-141.

Giller, K. E., Tittonell, P., Rufino, M. C., van Wijk, M. T., Zingore, S., Mapfumo, P., et al. (2011). Communicating complexity: integrated assessment of trade-offs concerning soil fertility management within African farming systems to support innovation and development. Agricultural Systems, 104(2), 191-203.

Hahn, M. B., Riederer, A. M., \& Stanley, O. F. (2009). The livelihood vulnerability index: a pragmatic approach to assessing risks from climate variability and change-A case study in Mozambique. Global Environmental Change, 19, 74-88.

Howard, J., Jeje, J., Tschirley, D., Strasberg, P., Crawford, E., \& Weber, M. (1998). What makes agricultural intensification profitable for Mozambican smallholders? An appraisal of the inputs subsector and the 1996/97 DNER/SG2000 Program. MSU International Department of Agricultural Economics (pp. 124). USA: Michigan State University.

INE (2011a). Censo Agro-Pecuário - CAP 2009-2010: Resultados definitivos - Moçambique. Maputo: Instituto Nacional de Estatística.

INE (2011b). III Censo Geral da População e Habitação 2007 . MaputoMoçambique: Instituto Nacional de Estatística.

Jones, S., \& Tarp, F. (2012). Jobs and Welfare in Mozambique. Country case study for the 2013 World Bank Report. World Development Reports. Background Papers (pp. 89): World Bank.

Jongman, R. H. G., Ter Braak, C. J. F., \& van Tongeren, O. F. R. (1995). Data analysis in community and landscape ecology (New edition ed.). Cambridge: Cambridge University Press.

Khan, S., Murray, R. P., \& Barnes, G. E. (2002). A structural equation model of the effect of poverty and unemployment on alcohol abuse. Addictive Behaviors, 27(3), 405-423. doi:10.1016/S0306-4603(01)00181-2.

Kirsten, J., \& Sartorius, K. (2002). Linking agribusiness and small-scale farmers in developing countries: is there a new role for contract farming? Development Southern Africa, 19(4), 503-529. doi:10. 1080/0376835022000019428.

Lanjouw, P., Quizon, J., \& Sparrow, R. (2001). Non-agricultural earnings in peri-urban areas of Tanzania: evidence from household survey data. Food Policy, 26(4), 385-403. doi:10.1016/S0306-9192(01) 00010-0.

Lawson, D., Mckay, A., \& Okidi, J. (2006). Poverty persistence and transitions in Uganda: a combined qualitative and quantitative analysis. Journal of Development Studies, 42(7), 1225-1251.

Lukanu, G., Green, M., \& Worth, S. (2007). The influence of smallholder labour demand on cultivation of cash crops in Northern Mozambique. Development Southern Africa, 24(4), 553-573.

Markelova, H., Meinzen-Dick, R., Hellin, J., \& Dohrn, S. (2009). Collective action for smallholder market access. Food Policy, 34(1), 1-7. doi:10.1016/j.foodpol.2008.10.001.

Milgroom, J., \& Giller, K. E. (2013). Courting the rain: rethinking seasonality and adaptation to recurrent drought in semi-arid southern Africa. Agricultural Systems, 118(0), 91-104. doi:10.1016/j.agsy. 2013.03.002.

MINAG. (2008a). Plano de Acção para a Produção de Alimentos. Maputo: Ministério da Agricultura. 144 pp.

MINAG (2008b). Trabalho de Inquérito Agrícola 2008. In D. d. Economia (Ed.). Ministério de Agricultura. Maputo.

MINAG. (2011). Plano Estratégico para o Desenvolvimento do Sector Agrário. PEDSA 2011-2020. Maputo: Ministério de Agricultura.

Moçambique, G. d. (2011). Plano de Acção para Redução da Pobreza (PARP) 2011-2014. (pp. 53). Maputo.

Moçambique, G. d. (2012). Diploma Ministerial nr 77. Maputo, Moçambique.

Rusinamhodzi, L., Corbeels, M., Nyamangara, J., \& Giller, K. E. (2012). Maize-grain legume intercropping is an attractive option for ecological intensification that reduces climatic risk for smallholder farmers in central Mozambique. Field Crops Research, 136, 12-22. doi:10. 1016/j.fcr.2012.07.014.

Sanchez, P. A., Shepherd, K. D., Soule, M. J., Place, F. M., Buresh, R. J., Izac, A.-M. N., et al. (1997). Soil fertility replenishment in Africa: an investment in naturalrResource capital. Replenishing Soil Fertility in Africa, sssaspecialpubl(replenishingsoi), 1-46, doi:10.2136/ sssaspecpub51.c1.

Schut, M., van Paassen, A., Leeuwis, C., Bos, S., Leonardo, W., \& Lerner, A. (2011). Space for innovation for sustainable community-based biofuel production and use: lessons learned for policy from Nhambita community, Mozambique. Energy Policy, 39(9), 5116-5128.

SDAE-Gondola. (2012). Relatório da campanha agrícola 2010-2011. In: S.D.d.A.E.d. Gondola (Ed.), Ministério de Agricultura. Gondola.

SDAE-Sussundenga. (2011). Relatório da campanha agrícola 2010-2011. In: S.D.d.A.E.d. Gondola (Ed.), Ministério de Agricultura.

Senthilkumar, K., Bindraban, P. S., de Boer, W., de Ridder, N., Thiyagarajan, T. M., \& Giller, K. E. (2009). Characterising ricebased farming systems to identify opportunities for adopting water efficient cultivation methods in Tamil Nadu, India. Agricultural Water Management, 96(12), 1851-1860.

SETSAN (2010). Relatório da Avaliação da Situação da Segurança Alimentar e Nutricional em Moçambique. Secretariado Técnico de Segurança Alimentar e Nutrição. Ministério de Agricultura. (pp. 67). Maputo.

Shepherd, K. D., \& Soule, M. J. (1998). Soil fertility management in west Kenya: dynamic simulation of productivity, profitability and sustainability at different resource endowment levels. Agriculture Ecosystems and Environment, 71(1-3), 131-145. doi:10.1016/ S0167-8809(98)00136-4.

Sousa, C. d. (1999). Rebuilding rural rivelihoods and social capital: Mozambique's experience. Working Papers. Helsinki United Nations University and World Institute for Development Economics Research (UNU-WIDER).

Stoorvogel, J. J., Smaling, E. M. A., \& Janssen, B. H. (1993). Calculating soil nutrient balances in Africa at different scales - I Supra-national scale. Fertilizer Research, 35(3), 227-235.

Tittonell, P. (2008). Targeting resources within diverse, heterogeneous and dynamic farming systems of East Africa. The Netherlands: Wageningen University.

Tschirley, D. L., Abdula, D. C., \& Weber, M. T. (2006). Toward improved maize marketing and trade policies to promote household food security in central and southern Mozambique. Food Security Collaborative Working Papers (pp. 43): Michigan State University. Department of Agricultural, Food, and Resource Economics.

Uaiene, R. (2004). Maize and sorghum technologies and the effects of marketing strategies on farmers' income in Mozambique. Purdue University.

Udo, H. M. J., Aklilu, H. A., Phong, L. T., Bosma, R. H., Budisatria, I. G. S., Patil, B. R., et al. (2011). Impact of intensification of different types of livestock production in smallholder crop-livestock systems. Livestock Science, 139(1-2), 22-29.

UNDP. (2011). Human Development Report 2011. Sustainability and equity: a better future for all. (pp. 185). New York: United Nations Development Programme.

USGS/FEWSNET (2011). Rainfall estimate by mean of remote sensing. Available at: http://earlywarning.usgs.gov/fews/africa/; August, 2013.

Woodhouse, P. (2010). Beyond industrial agriculture? Some questions about farm size, productivity and sustainability. Journal of Agrarian Change, 10(3), 437-453. doi:10.1111/j.1471-0366.2010. 00278.x.

World Bank. (2006). Mozambique Agricultural Development Strategy. Stimulating smallholder agricultural growth. AFTS1. Agriculture, Environment, and Social Development Unit. Country Department 2. Africa Region (pp. 123). Washington: World Bank. 


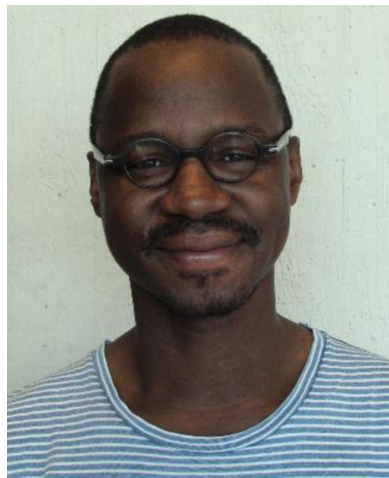

Wilson José Leonardo is a $\mathrm{PhD}$ candidate of Plant Production Systems at Wageningen University. Wilson's research focused on assessing the possibilities and limitations of improving land labour productivities of smallholder farming systems in Central Mozambique. In 2007 he obtained his Master's Degree in Plant Science from Wageningen University. In 2001 he graduated as a Bachelor of Plant Production and Protection at the Eduardo Mondlane University, Mozambique. He worked for the International Crop Research Institute for the Semi-Arid Tropics from 2001 to 2008 as a scientific officer, before joining Wageningen University for his $\mathrm{PhD}$ in 2009. Currently he is working for IFDC and IITA on the analysis of smallholder farming systems.

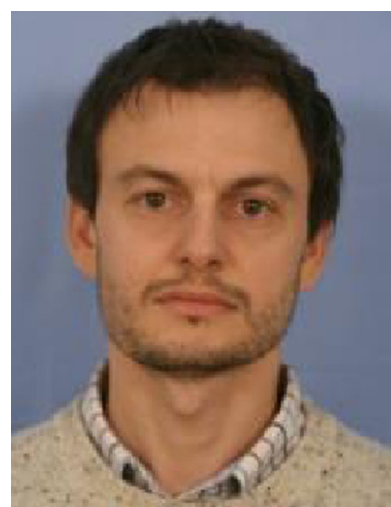

Argyris Kanellopoulos is involved as a post-doc researcher in a Top Institute Food and Nutrition (TIFN) project. His current research focuses on designing sustainable food supply chains in the Netherlands. He has 4 years of postdoctoral experience in Plant Productions Systems (PPS) group of Wageningen University. In PPS he was involved in a number of projects that aimed to assess adaptation of farmers to climate change. During his $\mathrm{PhD}$ in Wageningen University he was involved in a 6th framework EU project (SEAMLESS). He developed advanced bioeconomic models to simulate farmer's behavior across the EU to enable ex-ante evaluations of agricultural and environmental policies.

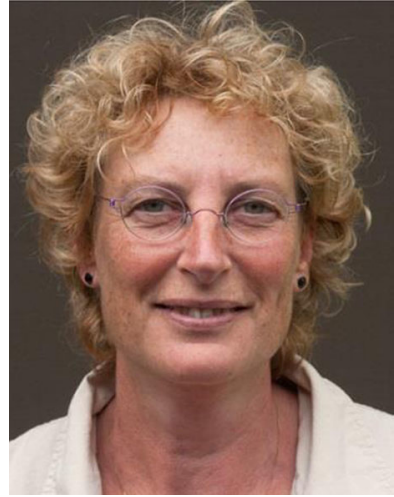

Dr ir. G.W.J. van de Ven Gerrie van de Ven is an environmental agronomist by training and has over 25 year experience working in the field of farming systems related to environmental and economic optimization. Especially, integrated assessment of farming systems at farm and regional level have her interest. Currently she is employed at Wageningen University working on both farming systems in the West European context and smallholder farming systems in Africa, with specific attention to biomass for fuel production and food security. She coordinates a scientific programme on this subject.

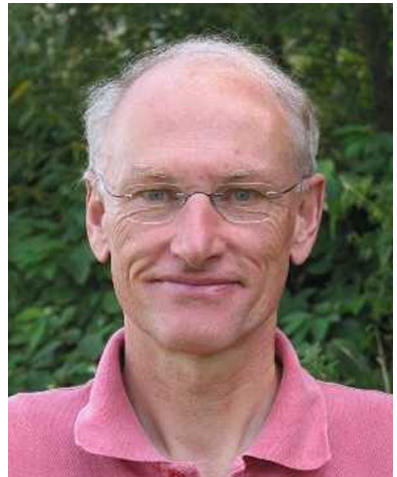

Henk Udo is an associate professor with the Animal Production Systems group at Wageningen University. He has long-term experience in international research, development and education programmes. His research focuses on sustainable intensification of smallholder livestock systems.

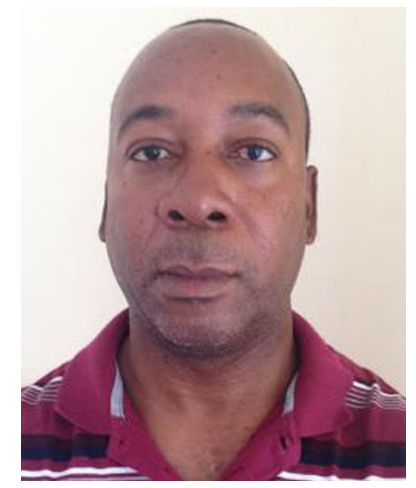

Almeida Sitoe has a Ph.D. in tropical forestry. He is Associate Professor of Silviculture and Ecology of Natural Forests at Eduardo Mondlane University, Maputo, Mozambique. His research is mainly in miombo woodlands resource use and dynamics, and impacts on livelihoods of smallholder farmers

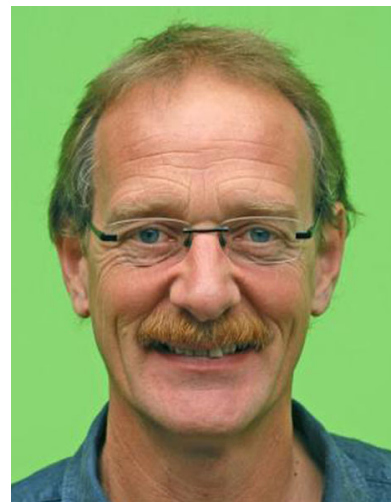

Ken Giller is Professor of Plant Production Systems at Wageningen University. He leads a group of scientists with profound experience in (farming) systems analysis and exploring future scenarios of change. Ken's research has focused on smallholder farming systems in subSaharan Africa, and in particular problems of soil fertility and the role of nitrogen fixation in tropical legumes. He is author of the book "Nitrogen Fixation in Tropical Cropping Systems". Ken joined Wageningen University in 2001 after holding professorships at Wye College, University of London, and the University of Zimbabwe. 